\title{
COMMENT
}

\section{A THIRTEENTH AMENDMENT DEFENSE OF THE VIOLENCE AGAINST WOMEN ACT}

\section{MARCELLENE ElIZABETH HEARN $\dagger$}

Section 1. Neither slavery nor involuntary servitude, except as a punishment for crime whereof the party shall have been duly convicted, shall exist within the United States, or any place subject to their jurisdiction.

Section 2. Congress shall have power to enforce this article by appropriate legislation.'

\section{INTRODUCTION}

In 1994, with bipartisan ${ }^{2}$ support, Congress passed the Violence Against Women Act ("the VAWA"). ${ }^{3}$ The most controversial part of the VAWA is a new civil rights cause of action for women who have been the victims of gender-motivated violent crimes. ${ }^{4}$ A woman who is a victim of a violent crime may now sue the person who battered, raped, or assaulted her for monetary damages, as well as for injunctive and declaratory relief. ${ }^{5}$ Congress's authority to create the remedy has

† J.D. Candidate 1998, University of Pennsylvania; B.A. 1991, Columbia University. I would like to thank Professor Seth Kreimer for his suggestions while I was forming my ideas for this Comment. I would also like to thank the editors of the Law Review for all of their help and support.

' U.S. CONST. amend. XIII.

${ }^{2}$ In 1993, Senators Joseph Biden (D-Del.) and Orrin Hatch (R-Or.) agreed to rewrite Biden's version of the Violence Against Women Act originally introduced in 1990. See Victoria F. Nourse, Where Violence, Relationship, and Equality Meet: The Violence Against Women Act's Civil Rights Remedy, 11 WIS. WOMEN's L.J. 1, 27 (1996).

${ }^{3}$ Pub. L. No. 103-322, tit. 4, 108 Stat. 1902 (codified as amended in scattered sections of 16, 18, 42 U.S.C.). Note that the Act was passed as title IV of the Violent Crime Control and Law Enforcement Act of 1994, Pub. L. No. 103-322, 108 Stat. 1796.

4 See 42 U.S.C. $\$ 13981$ (1994). For a discussion of the other provisions of the VAWA, see infra notes 26-32 and accompanying text.

${ }^{5}$ See 42 U.S.C. $\$ 13981$ (a). Because this Comment is about a statute that labels domestic violence, rape, assault, and other violent crimes perpetrated against women 
been challenged in six reported cases. ${ }^{6}$ Although Congress explicitly invoked its Fourteenth Amendment ${ }^{7}$ and commerce $^{8}$ powers to enact the civil rights remedy, this Comment argues that Section 2 of the Thirteenth Amer.dment is an alternative source of Congress's power to create a cause of action for private discrimination. ${ }^{9}$

A Thirteenth Amendment theory is necessary because there are powerful state action, privacy, and federalism arguments that Congress did not have the authority to enact the civil rights remedy under either the Commerce Clause or the Fourteenth Amendment.

The Fourteenth Amendment, for example, requires state action. ${ }^{10}$ The line between state action and private action is, in turn, influ-

as gender discrimination, I will use gendered pronouns to refer to the victims and perpetrators. In doing so, I express no opinion as to whether the remedy could be used in the context of same-sex violence. I use the term "victim" instead of the term "survivor" favored by many in the battered women's and antiviolence movements because the statute and the congressional debate speak in terms of "victims."

${ }^{6}$ See Crisonino v. New York City Hous. Auth., 985 F. Supp. 385 (S.D.N.Y. 1997) (upholding the constitutionality of the VAWA civil rights remedy under the Commerce Clause); Anisimov v. Lake, 982 F. Supp. 531 (N.D. Ill. 1997) (same); Seaton v. Seaton, 971 F. Supp. 1188 (E.D. Tenn. 1997) (same); Doe v. Hartz, 970 F. Supp. 1375 (N.D. Iowa 1997) (same), rev'd in part and vacated in part on other grounds, 134 F.3d 1339 (8th Cir. 1998); Doe v. Doe, 929 F. Supp. 608 (D. Conn. 1996) (same). But see Brzonkala v. Virginia Polytechnic \& State Univ., 935 F. Supp. 779 (W.D. Va. 1996) (holding that the VAWA civil rights remedy is an unconstitutional assertion of Congress's power, unjustified under either the 14th Amendment or the Commerce Clause), rev'd, 132 F.3d 949 (4th Cir. 1997), reh'g en banc granted and opinion vacated, WASH. POST, Feb. 8, 1998, at B3 (4th Cir. Feb. 5, 1998).

${ }^{7}$ See U.S. CONST. amend. XIV, § 1 ("No State shall ... deny to any person within its jurisdiction the equal protection of the laws."); id. $\S 5$ ("The Congress shall have power to enforce, by appropriate legislation, the provisions of this article.").

${ }^{8}$ See U.S. CONST. art. I, $\S 8, \mathrm{cl}$. 3 (giving Congress power ${ }^{\text {“ }}[\mathrm{t}]$ o regulate Commerce with foreign Nations, and among the several States, and with the Indian Tribes").

${ }^{9}$ This Comment is greatly influenced by Professor Akhil Amar's work on the expansive scope of the 13th Amendment, Professor Reva Siegel's work on the historical roots of the privacy doctrine, and Professor Joyce McConnell's work which first explored the possibility of applying the 13th Amendment to victims of domestic violence. See Akhil Reed Amar, Remember the Thirteenth, 10 CONST. COMMENT. 403 (1993) [hereinafter Amar, Remember the Thirteenth]; Akhil Reed Amar, Women and the Constitution, 18 HARV. J.L. \& PUB. POL'Y 465 (1995) [hereinafter Amar, Women and the Constitution] (providing a brief history of women and the Constitution); Akhil Reed Amar \& Daniel Widawsky, Child Abuse as Slavery: A Thirteenth Amendment Response to DeShaney, 105 HARV. L. REV. 1359 (1992) (applying the 13th Amendment to child abuse); Joyce E. McConnell, Beyond Metaphor: Battered Women, Involuntary Servitude and the Thirteenth Amendment, 4YALE J.L. \& FEMINISM 207 (1992); Reva B. Siegel, "The Rule of Love": Wife Beating as Prerogative and Privacy, 105 YALE L.J. 2117 (1996) (discussing the evolution of the legal treatment of marital violence).

${ }^{10}$ See The Civil Rights Cases, 109 U.S. 3, 13 (1883) ("[T]he prohibitions of the [14th A]mendment are against state laws and acts done under state authority."). 
enced by societal conceptions of the public and the private that have historically been used to deny women, and particularly married women, their legal rights. ${ }^{\text {"I }}$ The DeShaney case, in which the Supreme Court refused to extend Fourteenth Amendment substantive due process protection to a victim of child abuse because there was no affirmative state action, ${ }^{12}$ is a recent example of how the Supreme Court declines to apply the Fourteenth Amendment in so-called "private" arenas. A Thirteenth Amendment theory for the VAWA answers Fourteenth Amendment objections to the statute based on both the historical idea of privacy and the alleged lack of state action, because the Thirteenth Amendment reaches private action.

The VAWA also has been plagued by objections based on federalism. Critics argue that the VAWA will cause "state-federal jurisdictional problems," ${ }^{, 13}$ and place an undue burden on an already overburdened federal judiciary. ${ }^{14}$ Moreover, since the enactment of the VAWA, the legitimacy of broad congressional action under the Commerce Clause has been challenged in United States $v$. Lopez. ${ }^{15}$ Although there is a growing consensus among the lower courts that Congress had the power to enact the VAWA under the Commerce Clause, the question of the VAWA's constitutionality is not yet settled. $^{16}$ Should the Supreme Court or an appellate court strike down the VAWA under Lopez, a Thirteenth Amendment theory may provide an alternative basis for upholding the civil rights remedy. ${ }^{17} \mathrm{~A}$ Thirteenth Amendment theory answers federalism objections to the

"See, e.g., Siegel, supra note 9, at 2177 (observing that in the Reconstruction period " $[t]$ he racial discourse of the private that the Court invoked ... differed from the discourses of affective privacy employed to rationalize elements of marital status law," but arguing that the discourses "functioned in strikingly similar ways: to explain laws enforcing status privileges, once justified in overtly hierarchy-based discourses, with reference to other, less contested, social values"); Nadine Taub \& Elizabeth $M$. Schneider, Women's Subordination and the Role of Law, in THE POLITICS OF LAW 151 (David Kairys ed., rev. ed. 1990) (explaining how the law subordinates women by refusing to regulate the private sphere); infra Part II.A.2 (explaining the relationship between the ideal of marital privacy and the legal treatment of violence against women).

${ }^{12}$ DeShaney v. Winnebago County Dep't of Soc. Servs., 489 U.S. 189 (1989); see infra Part II.A.1.

${ }^{13}$ See infra note 171 and accompanying text.

14 See infra Part II.A.3.

${ }^{15} 514$ U.S. 549, 566-68 (1995) (holding that a statute making possession of a firearm in a school zone a federal offense exceeded Congress's authority under the Commerce Clause).

${ }^{16}$ See infra Part II.C.

${ }^{17}$ See infra Part II.C. 
VAWA because the Thirteenth Amendment represented a reordering of state and federal relations. ${ }^{18}$

Although the traditional view is that the Thirteenth Amendment applies only to systems of labor which are analogous to chattel slavery and/or to racial discrimination, ${ }^{19}$ this Comment follows the trend of more recent scholarship and argues that the Thirteenth Amendment should be viewed more comprehensively. ${ }^{20}$ Slavery involved familial and private aspects of which Congress was well aware when it passed the Thirteenth Amendment. ${ }^{21}$ If the Thirteenth Amendment is an abolition of slavery and involuntary servitude for all time, then it should abolish any form of servitude found in the twentieth century. ${ }^{22}$ Congress has the authority to legislate against "badges and incidents" of slavery and involuntary servitude, ${ }^{23}$ and this Comment will argue that violence against women is such an incident.

Part $I$ discusses the VAWA civil rights remedy. It explains the significance of a civil rights remedy in Part I.A; the advantages of this remedy in Part I.B; the actual provisions of the VAWA civil rights remedy in Part I.C; parallels to Reconstruction-era civil rights statutes in Part I.D; and Congress's claims of authority to enact the remedy under the Fourteenth Amendment and the Commerce Clause in Part I.E.

Part II discusses arguments that have been or may be used against the civil rights remedy. Part II.A.1 details arguments grounded in the notion of state action; Part II.A.2 explains arguments grounded in privacy; Part II.A.3 addresses federalism arguments; and Part II.A.4 discusses Lopez. Part II.B explains the federal court challenges to the VAWA. Part II.C concludes by arguing the need for an alternative constitutional basis for the civil rights remedy.

Part III begins with an explanation of the traditional interpretation of Congress's Thirteenth Amendment powers. Part III.B proposes a Thirteenth Amendment basis for the VAWA as an alternative to that interpretation. Part III.C presents a working definition of

${ }^{18}$ See infra note 278 and accompanying text.

19 See infra Part III.A.

${ }^{20}$ See sources cited infra note 283.

${ }^{21}$ See infra Part III.C.

${ }^{22}$ See Slaughter-House Cases, 83 U.S. (16 Wall.) 36, 72 (1872) (“[W]hile negro slavery alone was in the mind of the Congress which proposed the thirteenth article, it forbids any other kind of slavery, now or hereafter.").

${ }^{23}$ See The Civil Rights Cases, 109 U.S. 3, 28 (1883) (stating that the 13th Amendment "clothes congress with power to pass all laws necessary and proper for abolishing all badges and incidents of slavery in the United States"). 
slavery that encompasses the differential experience of slave women-including gender-differentiated physical and sexual violence-and rejects the notion that the Thirteenth Amendment addresses only labor relations. Part III.D debunks the common wisdom that Congress never intended the Thirteenth Amendment to apply to women by demonstrating that contemporaneous political actors thought the Amendment had the potential to reorder familial relationships. Part III.E counters the argument that gender discrimination has been expressly removed from the Thirteenth Amendment's purview by the Supreme Court in Griffin v. Breckenridge and its progeny. Finally, Part III.F argues that Congress had the authority to enact the VAWA to address severe battering and child abuse, which are present-day forms of involuntary servitude, and Part III.G presents the proposition that violence against women today is an incident of both nineteenth-century slavery and marriage.

\section{THE CIVIL RIGHTS REMEDY OF THE VAWA}

The VAWA ${ }^{24}$ was passed in 1994 as part of the Violent Crime Control and Law Enforcement Act of 1994. ${ }^{25}$ The statute includes a wide variety of measures intended to address violence against women. For example, it creates the federal criminal offenses of interstate domestic violence, interstate stalking, and interstate violation of a protective order. $^{26}$ It also provides mandatory restitution to victims of federal sex crimes; ${ }^{27}$ legislates full faith and credit in each state for an order

${ }^{24}$ Violence Against Women Act of 1994, Pub. L. No. 103-322, tit. 4, 108 Stat. 1902 (codified as amended in scattered sections of 16, 28, 42 U.S.C.).

${ }^{25}$ Pub. L. No. 103-322, 108 Stat. 1796.

${ }^{26}$ See 18 U.S.C $\$ \$ 2261-2262$ (1994). Like the civil rights remedy, the interstate domestic violence provisions have been challenged as invalid exercises of Congress's commerce power. See United States v. Wright, 128 F.3d 1274 (8th Cir. 1997) (upholding $\$ 2262$ (a) (1) under the Commerce Clause), cert. denied, No. 97-8095, 1998 WL 99344 (U.S. Mar. 30, 1998); United States v. Bailey, 112 F.3d 758, 766 (4th Cir.) (upholding $\$ 2261$ (a) as a valid exercise of Commerce Clause powers by comparing the statute to the White Slave Traffic Act of 1910 and the Mann Act), cert. denied, 118 S. Ct. 240 (1997); United States v. Gluzman, 953 F. Supp. 84, 92 (S.D.N.Y. 1997) (holding that Congress had the constitutional authority to pass $\S 2261$ as a means of regulating interstate commerce).

${ }^{27}$ See 18 U.S.C. $\S 2248$ (providing that those convicted of a chapter $109 \mathrm{~A}$ sexual offense must compensate the victim for the cost of medical care, physical therapy, lost income, attorney's fees, and "any other losses suffered by the victim as a proximate result of the offense"); id. $\$ 2259$ (providing identical restitution to victims of child sexual abuse). 
of protection issued in any other state; ${ }^{28}$ creates a national domestic abuse hotline; ${ }^{29}$ supplies grants for the coordination of domestic violence prevention programs among local government and community groups, ${ }^{30}$ and provides for and funds education and training programs for judges regarding gender-motivated crimes. ${ }^{31}$ In addition, the VAWA changed the citizenship petitioning procedure for battered aliens and their children. ${ }^{32}$

The most controversial part of the VAWA and the subject of this Comment, however, is the civil rights remedy, which creates both a substantive right to be free from gender-motivated violence and a cause of action to enforce this right.

\section{A. The VAWA Civil Rights Remedy Establishes That Crimes of Violence Motivated by Gender Are Civil Rights Violations}

Congress enacted the civil rights remedy of the VAWA to provide a new "[f]ederal civil rights cause of action for victims of crimes of

${ }^{28}$ See id. $\$ 2265$ (ordering state courts to honor all protective orders issued in other states or by Indian tribal courts). States have varying requirements for the relationship between the seeker of a domestic protective order and the abuser. In some states, protective orders are available only to women who are or have been married to, who share a child with, or who have cohabited with the batterer. See, e.g., D.C. CODE ANN. \$ 16-1001(5) (a) (1997) (requiring that a complainant in an intrafamily offense be related to the offender by "blood, legal custody, marriage, having a child in common," or by having shared a residence).

29 See 42 U.S.C. $\$ 10416$.

so See id. $\$ 10418$.

31 See id. $\$$ 13991-13992, 14036.

${ }^{32}$ See Violence Against Women Act of 1994, Pub. L. No. 103-322, tit. 4, $\$ 40701$ (a), 108 Stat. 1902, 1953-55 (amending 8 U.S.C. $\$ 1154$ (a) (1988 \& Supp. V 1993)) (describing the petitioning procedure for battered aliens and the children of battered aliens). For a discussion of the particular problems faced by battered immigrant women prior to the enactment of the VAWA, see Michelle J. Anderson, Note, A License to Abrese: The Impact of Conditional Status on Female Immigrants, 102 YALE L.J. 1401 (1993), which argues that the prior legal regime acted to keep immigrant women in relationships with abusive citizen or legal-resident spouses upon pain of deportation.

${ }^{33}$ See 42 U.S.C. \$ 13981. For a discussion of the political and legislative struggles in enacting the civil rights remedy, see Panel Discussion, The Civil Rights Remedy of the Violence Against Women Act: Legislative History, Policy Implications \& Litigation Strategy, 4J.L. \& POL'Y 383 (1996) [hereinafter Panel Discussion]; see also Nourse, supra note 2, at 8 (detailing the complete history of the VAWA from 1990 until its adoption, including hearings, testimony, and changes made in committee); Patricia Schroeder, Stopping Violence Against Women Still Takes a Fight: If in Doubt Just Look at the 104th Congress, 4 J.L. \& POL'Y 377 (1996) (describing funding issues related to the VAWA); $c f$. Siegel, supra note 9 , at 2198 (discussing the opposition to the civil rights remedy by the federal judiciary). 
violence motivated by gender." ${ }^{34}$ A woman who can prove all of the elements of a crime of violence motivated by gender ${ }^{35}$ may sue for "compensatory and punitive damages, injunctive and declaratory relief." ${ }^{36}$ The VAWA also covers deprivations occurring "under color" of state law. ${ }^{37}$ Congress intended that the VAWA remedy would supplement the existing pantheon of federal civil rights causes of action, ${ }^{38}$ specifically, 42 U.S.C. $\S \S 1981,{ }^{39} 1983,{ }^{40}$ and 1985(3). ${ }^{41}$ Those sections do not cover private gender-discriminatory violence against women perpetrated by a single individual. Section 1983 requires state action; ${ }^{42} \S 1985(3)$ requires a conspiracy of two or more persons; ${ }^{43}$ and

s4 42 U.S.C. $\$ 13981$ (a). This section provides:

Pursuant to the affirmative power of Congress to enact this part under section 5 of the Fourteenth Amendment to the Constitution, as well as under section 8 of Article I of the Constitution, it is the purpose of this part to protect the civil rights of victims of gender motivated violence and to promote public safety, health, and activities affecting interstate commerce by establishing a Federal civil rights cause of action for victims of crimes of violence motivated Id. by gender.

ss See infra Part I.C.
${ }_{s 5} 42$ U.S.C. $\$ 13981$ (c). This provision states:

A person (including a person who acts under color of any statute, ordinance, regulation, custom, or usage of any State) who commits a crime of violence motivated by gender and thus deprives another of the right declared in subsection (b) of this section shall be liable to the party injured, in an action for the recovery of compensatory and punitive damages, injunctive and deId. claratory relief, and such other relief as a court may deem appropriate.

${ }^{97}$ See id. Note that the "under color of" language tracks the language in 42 U.S.C. $\S 1983$; see also S. REP. No. 103-138, at 53 (1993) (explaining that the "under color of law" language should be interpreted in the same manner as 42 U.S.C. $\$ 1983$ ).

s See S. REP. No. 103-138, at 50-53 (describing the VAWA as an "extension" of the existing civil rights laws). ties).

42 U.S.C. $\$ 1981$ (providing for enforcement of equal rights for racial minori-

${ }^{40} I d . \S 1983$ (providing a remedy when civil rights have been violated under color of state law); see Monroe v. Pape, 365 U.S. 167, 187 (1960) (confirming that civil rights violations performed under color of state law subject the violator to $\S 1983$ liability whether or not the violator was acting within the bounds of state law).

${ }^{11} 42$ U.S.C. $\$ 1985$ (3) (providing a civil rights remedy to victims of private conspiracies for deprivation of constitutional rights, privileges, and immunities).

${ }^{12}$ See Lugar v. Edmondson Oil Co., 457 U.S. 922, 934 (1982) (stating that § 1983 requires state action because it is derived from the Civil Rights Acts of 1871 enacted to enforce the 14th Amendment).

${ }^{43}$ See 42 U.S.C. $\$ 1985$ (3); S. REP. No. 102-197, at 42 (1993) (“[Section] 1985 has been largely unavailable to women for two reasons. First, it is an unsettled question whether section 1985(3) applies to claims of sexual discrimination. Second, the stat- 


\section{$\S 1981$ is limited to racial discrimination. ${ }^{44}$}

Although the language and purpose of the VAWA echo its Reconstruction predecessors, the VAWA civil rights remedy is distinct because it creates a new substantive right-the right to be free from "crimes of violence motivated by gender," ${ }^{45}$ and the vehicle for enforcement of this right-the civil rights remedy. ${ }^{46}$ The VAWA civil rights remedy represents the first time Congress has declared that violence against women is gender discrimination. ${ }^{47}$ The House Conference Report, for example, states that "Congress has found that crimes of violence motivated by gender constitute bias crimes in violation of the victim's right to be free from discrimination on the basis of gender."

\section{B. The Civil Rights Remedy Provides Key Advantages over Existing State Laws}

In addition to serving the important societal function ${ }^{49}$ of recognizing that violence against women is gender discrimination, the VAWA remedy has distinct advantages over existing state laws. First, the VAWA provides civil relief where the State refuses to prosecute criminally because of the relationship between the victim and the

ute requires more than one perpetrator... leaving most gender-motivated crimes against women unprotected."). For further discussion of the debate on whether $\$ 1985$ (3) covers women, see infra Part III.E.

${ }^{14}$ See, e.g., Bobo v. ITT, Continental Baking Co., 662 F.2d 340, 344 (5th Cir. Nov. 1981) (holding that $\$ 1981$ "applies only to race"). Section 1981 is widely assumed not to cover sex discrimination. See generally id. at 344, nn.6-7 (listing 27 district court and five court of appeals decisions concluding that "gender discrimination is not within the acts forbidden by $\left.\S 1981^{\prime \prime}\right)$.

${ }^{45} 42$ U.S.C. $\$ 13981$ (b).

${ }^{16}$ The basic structure of the statute is as follows: statement of purpose, declaration of the right to be free from crimes of violence motivated by gender, cause of action for deprivation of the right, definition of crime of violence motivated by gender, and limitations and procedure. See id. $\$ 13981$.

${ }^{47}$ See Nourse, supra note 2 , at 5 (characterizing the civil rights remedy as "unprecedented"); Siegel, supra note 9, at 2197 (stating that the remedy "broke new ground").

${ }^{48}$ H.R. CONF. REP. NO. 103-711, at 385 (1994); see also S. REP. No. 103-138, at 48 (1993) ("The Violence Against Women Act recognizes that gender discrimination may take the form not only of a lost pay raise or promotion, but also a violent, criminal attack.").

${ }^{49}$ See S. REP. NO. 103-138, at 50 (declaring that the civil rights remedy "provid[es] a special societal judgment that crimes motivated by gender bias are unacceptable because they violate the victims' civil rights"); see also Andrea Brenneke, Civil Rights Remedies for Battered Women: Axiomatic E Ignored, 11 LAW \& INEQ. J. 1, 44 (1992) ("The distinct advantage to civil rights causes of actions [sic], like criminal prosecutions, is that violations constitute attacks on socially held norms of human decency, not individual or 'private' harms."). 
perpetrator..$^{50}$ For example, although nearly every state has abolished the complete marital rape exemption, many states still prosecute rape within marriage differently than rape outside marriage. Some states only prosecute when the couple has separated or has begun divorce proceedings; ${ }^{51}$ other states criminalize only first-degree rape, or rape where force is used. ${ }^{52}$ Some states even have extended the marital rape exemption to cover cohabitants. ${ }^{53}$ Delaware has gone so far as to exempt voluntary social companions from prosecution for rape unless there is additional serious injury. ${ }^{54}$

Second, the VAWA provides a federal forum and cause of action to plaintiffs who are precluded by state law from bringing a state civil cause of action. Some states, for example, limit a wife's ability to sue her husband for an intentional tort such as battery. ${ }^{55}$ Third, Congress amended 42 U.S.C. $\S 1988$ so that a court can award reasonable attorney's fees to the prevailing party in a VAWA action. ${ }^{56}$ Finally, un-

${ }^{50}$ See 42 U.S.C. $\$ 13981$ (d) (2)(B). According to Victoria Nourse, this provision was added to counteract state statutes which downgrade violent crimes against women that would be felonies but for the relationship between the perpetrator and victim. See Nourse, supra note 2, at 28 ("[T]he drafters added language explicitly stating ... the 'acts' ... must be considered separate and apart from the relationship of the victim and the perpetrator.").

${ }^{51}$ See Robin West, Equality Theory, Marital Rape, and the Promise of the Fourteenth Amendment, 42 FLA. L. REV. 45, 47-48 nn.9-10 (1990) (listing state statutes modifying the marital rape exemption where the couple is separated or has begun proceedings).

${ }_{32}$ See, e.g., S. REP. No. 103-138, at 47 (noting that some states fail to prosecute marital rape unless the wife suffered "additional degrees of violence like kidnapping or being threatened with a weapon," and that others refuse to prosecute when the wife is "unconscious, drugged, asleep, ill, or physically or mentally helpless"); West, supra note 51 , at 46 n. 6 (detailing 21 state statutes that criminalize only certain degrees or types of sex crimes within marriage); cf. Jaye Sitton, Comment, Old Wine in New Bottles: The "Marital" Rape Allowance, 72 N.C. L. REV. 261 (1993) (arguing that although most states have abolished the exemption by statute or by decision, the exemption is qualified in many states, leaving married women without protection from some varieties of sexual assault).

${ }^{39}$ See S. REP. NO. 102-197, at 45 n.50 (1991) (commenting that some states have extended marital rape rules to nonmarried cohabitants); see also West, supra note 51, at 48 n.11 (citing CONN. GEN. STAT. ANN. \$ 53a-70(b) (West 1985); KY. REV. STAT. ANN. $\S 510.010$ (3) (Banks-Baldwin 1989); MONT. CODE ANN. § 45-5-511 (1989); N.M. STAT. ANN. § 30-9-10 (Michie 1989); 18 PA. ConS. STAT. ANN. § 3103 (West 1983)).

34 See DEL. CODE ANN. tit. 11, \$\$ 774775 (1997).

${ }^{35}$ See Panel Discussion, supra note 33, at 407 (statement of Betty Levinson) (claiming that although many states have abolished interspousal immunity for intentional torts, there have been few successful suits, and many such suits are precluded by short statutes of limitation). The VAWA includes a four-year statute of limitation. See 28 U.S.C. $\S 1658$.

${ }^{56}$ See Violence Against Women Act of 1994, Pub. L. No. 103-322, tit. 4, § 40303, 108 Stat. 1902, 1942 (amending 42 U.S.C. $\$ 1988$ ) (providing for the same award of attor- 
der the VAWA, a plaintiff may obtain a permanent injunctive order forbidding a defendant from contacting her, whereas many state-law orders of protection last only for a specified duration. ${ }^{57}$

\section{Elements of a Crime of Violence Motivated by Gender}

To establish a cause of action under the civil rights remedy, a plaintiff must prove that a defendant committed a "crime[] of violence motivated by gender. ${ }^{58}$ A crime of violence motivated by gender has two elements: First, it must rise to the level of a federal or state felony that also would be a statutory crime of violence under 18 U.S.C. $\S 16 ;^{59}$ and second, it must be committed with gendermotivated animus. ${ }^{60}$

\section{Crime of Violence}

The VAWA focuses on the act committed by the perpetrator. A plaintiff must prove that the perpetrator's conduct met the actus reus elements of a felony against either a person or against property serious enough to be an 18 U.S.C. $\$ 16$ crime of violence. ${ }^{61}$ Some exam-

ney's fees for $\S 13981$ actions as for $\$ \S 1981,1983$, and $1985(3)$ and other civil rights causes of action).

${ }^{37}$ See, e.g., Panel Discussion, supra note 33, at 406 (statement of Betty Levinson) (explaining that in New York, family court orders of protection have a maximum life of three years and criminal court orders last no more than five years after conviction).

${ }^{59} 42$ U.S.C. \$ 13981 (a); see supra note 34 (quoting this section of the VAWA).

${ }^{59}$ See 42 U.S.C. $\S 13981$ (c)-(d); 18 id. $\S 16(a)$. The VAWA defines a crime of violence as:

(A) an act or series of acts that would constitute a felony against the person or that would constitute a felony against property if the conduct presents a serious risk of physical injury to another, and that would come within the meaning of State or Federal offenses described in section 16 of Title 18, whether or not those acts have actually resulted in criminal charges, prosecution, or conviction and whether or not those acts were committed in the special maritime, territorial, or prison jurisdiction of the United States; and

(B) includes an act or series of acts that would constitute a felony described in subparagraph (A) but for the relationship between the person who takes such action and the individual against whom such action is taken.

42 id. $\$ 13981$ (d) (2).

${ }_{60}$ See 42 id. $\$ 13981$ (d).

${ }^{61}$ Section 16 defines a crime of violence as:

(a) an offense that has as an element the use, attempted use, or threatened use of physical force against the person or property of another, or

(b) any other offense that is a felony and that, by its nature, involves a substantial risk that physical force against the person or property of another may be used in the course of committing the offense. 
ples of felonies against persons in the federal criminal code that qualify as crimes of violence are: aggravated sexual assault, ${ }^{62}$ child sexual abuse, kidnapping, murder, and felonious assault. ${ }^{63}$ A felony against property must both meet the 18 U.S.C. $\S 16$ threshold and "present[] a serious risk of physical injury to another" to form the basis for a VAWA claim. ${ }^{64}$ The underlying felony, or "predicate offense," be a state or federal felony. ${ }^{66}$ The defendant need not have been prosecuted or convicted of the underlying felony. ${ }^{67}$

\section{Gender-Motivated Animus}

The VAWA defines the "motivated by gender" element of a "crime of violence motivated by gender" as: "a crime of violence committed because of gender or on the basis of gender, and due, at least in part, to an animus based on the victim's gender." Congress modeled this animus requirement on the "invidious class based animus" requirement of 42 U.S.G. $\$ 1985$ (3) as interpreted in Griffin v. Breckenridge $e^{69}$ and its progeny. The VAWA language tracks language from

18 id. $\S 16$ (emphasis added). Section 16 (a) refers to misdemeanors or felonies that specifically require the use or threat of force as a defining element of the offense, and $\S 16$ (b) refers to felonies that do not list force or threat of force as a required element, but that, based on the act itself, assume there is a risk that force will be used.

According to Victoria Nourse, the Senate Judiciary Committee added the requirement that a gender-motivated crime meet the threshold of 18 U.S.C $\$ 16$ in 1990, in response to Department of Justice concerns that the then-current version of the bill did not define clearly a crime of violence. See Nourse, supra note 2 , at 12 . Once the threshold was added, "[ $t$ ] he new emphasis was on the 'acts' at issue-i.e. the actus reus associated with a criminal offense. The question was categorical: whether the acts alleged fit within the category of offenses enumerated in section 16." Id. at 14 (citations and footnote omitted).

62 "Aggravated sexual assault" is the federal-law equivalent to rape. See 18 U.S.C. $\S 2241$ (defining aggravated sexual assault as causing another person to engage in sexual acts by force, threat, or other means).

${ }^{63}$ Of course, the "predicate offense" may also be a state-law felony. For an example of a court's analysis of a state criminal statute in the context of the VAWA, see Doe v. Hartz, 134 F.3d 1339, 1342-44 (8th Cir. 1998).

64 42 U.S.C. $\$ 13981$ (d) (2)(A); see alsoS. REP. No. 103-138, at 52 (1993).

os Doe v. Hartz, 134 F.3d 1339, 1342 (8th Cir. 1998).

${ }^{66}$ See 42 U.S.C. $\$ 13981$ (d) (2)(A).

${ }^{67}$ See id. $\S 13981$ (d); id. $\S 13981$ (e)(2) ("Nothing in this section requires a prior criminal complaint, prosecution, or conviction to establish the elements of a cause of action under subsection (c) of this section."); see also Doe v. Doe, 929 F. Supp. 608, 611-12 (D. Conn. 1996) ("The statute does not require a prior criminal complaint, prosecution, or conviction to establish the elements of the cause of action.")

6s 42 U.S.C. $\$ 13981$ (d) (emphasis added).

${ }^{69} 403$ U.S. 88, 102 (1971) (requiring an "invidiously discriminatory animus behind the conspirators' action [s]" for a $\S 1985$ (3) cause of action). 
an equal protection case, Personnel Administrator $v$. Feeney, ${ }^{70}$ imported into the proof requirements for a $\$ 1985$ (3) claim by the Court in Bray v. Alexandria Women's Health Clinic. ${ }^{71}$ The animus requirement was inserted to prevent the VAWA remedy from converting every violent crime committed against a woman into a federal tort claim. ${ }^{72}$ To this end, the Senate clearly stated that "random" crimes are excluded from coverage by the VAWA civil rights remedy. ${ }^{73}$

The 1993 Senate Report explaining the addition of the animus requirement ${ }^{74}$ defined animus as "a specific intent or purpose, based on the victim's gender, to injure the victim."75 The Report divided gender-motivated animus into two parts: First, the violent act must be "committed because of gender or on the basis of gender," and second, the violent act must be "due, at least in part, to an animus based on the victim's gender." 77 The Senate Report gives the following example of how this two-part test should be applied: A man goes on a shooting spree in a department store, shoots only women, and yells "I hate women." The fact that he shot only women is evidence that he is motivated by gender, and his comment is evidence of his animus. ${ }^{78}$ In

${ }^{70} 442$ U.S. 256, 279 (1979) (defining "discriminatory purpose" in the equal protection context).

${ }^{71} 506$ U.S. 263, 271-72 (1993) ("“u Discriminatory purpose" .... implies that the decisionmaker ... selected ... a particular course of action at least in part "because of," not merely "in spite of," its adverse effects upon an identifiable group.' The same principle applies to the 'class-based, invidiously discriminatory animus' requirement of $\$ 1985$ (3)." (citation and footnote omitted) (emphasis added) (second omission in original) (quoting Feeney, 442 U.S. at 279)).

${ }_{72}$ See S. REP. No. 103-138, at 51 (1993) ("Congress does not create a "Federal tort law' when it legislates a civil rights remedy for violent acts based on discriminatory motivation." (citing Griffin, 403 U.S. at 102)).

${ }^{73}$ See S. REP. NO. 102-197, at 48 (1991).

${ }^{74}$ Nourse explains that the animus requirement as enacted represented a compromise between a "malice" or "animosity" standard requiring "proof that the defendant ... hated all members of the opposite sex or consciously intended to use violence as a message of gender hatred" and a "disparate impact" standard requiring only proof that the particular act in question "disproportionately affected women." Nourse, supra note 2, at 29-30.

${ }^{75}$ S. REP. NO. 103-138, at 64.

${ }^{76} I d$. at 50.

${ }^{77} I d$.

${ }^{78}$ See id. at 51 (setting forth this example and explaining the kind of evidence needed to prove animus). Senator Orrin Hatch provides an absurd articulation of the distinction that reveals a misunderstanding of rape:

"Say you have a man who believes a woman is attractive.... [H]e's so motivated... that he rips her clothes off and has sex with her against her will. Now let's say you have another man who grabs a woman off some lonely road and in the process of raping her says words like... 'You're a woman! I hate 
practical terms, it is difficult to distinguish between motivation and animus.

Some commentators have argued for a broad interpretation of the animus standard. Victoria Nourse explains that animus means "purpose":

Consciousness of bias is not required: a plaintiff states a claim ... if ... she can show that the crime or victim was purposefully chosen because of "the victim's gender." That includes acts used to enforce, by violence, stereotypical gender-roles, to punish the victim for the exercise of rights guaranteed to all citizens, or to use forced sex as a weapon of intimidation or degradation. ${ }^{79}$

Nourse's definition includes more than the obvious case of the screaming department-store shooter; it encompasses violence motivated by gender in other ways, such as the violent perpetuation of outdated stereotypes of women. In each VAWA case, it is a question of fact whether a particular perpetrator committed the crime of violence with gender-motivated animus. ${ }^{80}$

\section{The VAWA as a Modern Version of the Reconstruction-Era Civil Rights Acts}

Congress conceived of the VAWA as the modern-day gender ver$\operatorname{sion}^{81}$ of the Civil Rights Act of $1871,{ }^{82}$ which included the precursors to both 42 U.S.C. $\S 1983$, premised on the Fourteenth Amendment, and $\S 1985(3)$, premised on the Thirteenth Amendment. ${ }^{83}$ Congress enacted the Civil Rights Act of 1871 in reaction to rampant violence

women!' . . . Now, the first one's terrible. But the other's much worse. If a man rapes a woman while telling her he loves her, that's a far cry from saying he hates her...."

Ruth Shalit, Caught in the Act, NEw REPUBLIC, July 12, 1993, at 12, 15 (quoting Senator Hatch). For an argument that Senator Hatch's statement reflects a view that animus requires actual malice, see Siegel, supra note 9, at 2200.

79 Nourse, supra note 2, at 31.

${ }^{80}$ See S. REP. No. 103-138, at 50 (stating that proof on a case-by-case basis is required).

${ }^{81}$ See id. at 48 (introducing the new civil rights remedy by stating that "[o]ver a century ago, society declared that it would not tolerate attacks against persons because of their race, religion, or national origin. Congress passed the first civil rights laws barring such discrimination in 1871."). The Senate also placed the VAWA in the context of recent federal legislation outlawing hate crimes that did not even mention crimes motivated by gender. See id. ("More recent legislation has not filled the 'gender gap' left by traditional anti-bias crime laws.").

${ }^{82}$ The Civil Rights Act of 1871, ch.22, 17 Stat. 13 (codified as amended at 42 U.S.C. $\S 1983$ (1994)).

${ }^{83}$ See supra notes $40-41$; infra Part III.E. 
against African-Americans in the South after the Civil War. ${ }^{84}$ Just as Congress in the 1870 s gathered evidence concerning racial violence and enacted the 1871 Act, Congress in the 1990s gathered evidence concerning gender-motivated violence against women, ${ }^{85}$ and enacted the VAWA civil rights remedy.

In 1871, Congress decided that a federal remedy was needed for African-Americans whose rights were being denied by private citizens and by the state because: (1) state law did not exist to address the problem; (2) state-law remedies were inadequate; and (3) the state laws that did exist were not being enforced equally, or at all. ${ }^{86}$ In 1994, as the next three sections will demonstrate, Congress enacted the VAWA for the same reasons.

\section{Congress Gathered Evidence That Violence Against Women Is Widespread ${ }^{87}$}

Hearing testimony revealed, ${ }^{88}$ and the Senate Committee Reports concluded, that violence against women is widespread. The Senate found that "[v]iolence is the leading cause of injuries to women ages 15 to 44 , more common than automobile accidents, muggings and cancer

${ }^{84}$ See Monroe v. Pape, 365 U.S. 167, 174 (1961), overruled in part by Monell v. Department of Soc. Servs., 436 U.S. 658 (1978). Monroe stated:

This Act of April 20,1871 ... was passed by a Congress that had the Klan 'particularly in mind.' The debates are replete with references to the lawless conditions existing in the South in 1871 . There was available to the Congress during these debates a report, nearly 600 pages in length, dealing with the activities of the Klan and the inability of the state governments to cope with it. This report was drawn on by many of the speakers.

Id.

${ }^{85}$ In the early 1990 s, three hearings were held concerning the first iteration of the VAWA civil rights remedy, Senate Bill 2754. These hearings addressed the prevalence of violent crimes against women and the barriers women faced in obtaining justice. For details of the hearings held and resulting changes in the legislation, see Nourse, supra note 2.

${ }^{86}$ See Monroe, 365 U.S. at $173-75$ (discussing the legislative history of $\$ 1983$ ).

${ }^{87}$ This section relies heavily on the use of the statistics appearing in the Senate and House reports preceding the passage of the VAWA. I use the statistics to demonstrate the scope of evidence available to Congress. I hope that the sheer volume of statistics will not, as Martha Minow has argued, enable the reader to disengage with the problem of violence against women. See Martha Minow, Words and the Door to the Land of Change: Law, Language, and Family Violence, 43 VAND. L. REV. 1665, 1685 (1990) ("The language used to describe individual stories may create a sense of drama and urgency, yet it hides the scope of the problem; the language of trends and populations may cover the scope, but it undermines the sense of personal connection and individual obligation to effectuate change.").

${ }^{88}$ See supra note 85 (detailing hearings held on the VAWA). 
deaths combined. ${ }^{n 9}$ Violence is perpetrated upon women by people they love. In 1989, three to four million women were abused by their husbands. ${ }^{90}$ The U.S. Department of Justice estimated that from 1992 to 1993, seventy-five percent of all violence perpetrated against women by a "lone offender" was by someone the woman knew; twenty-nine percent of all "lone-offender" violence was committed by an ex- or current husband or lover. ${ }^{91}$ Intimate violence is serious. "As many as 20 percent of hospital emergency room cases are related to wife battering. ${ }^{.92}$ The Department of Justice estimated that if all domestic attacks were reported, one-third would qualify as "felony rape, robbery, or aggravated assault." ${ }^{93}$ One in six sexual assaults a week is committed by a family member. ${ }^{94}$ Intimate violence is deadly. "[F]amily violence accounts for a significant number of murders in this country. One-third of all women who are murdered die at the hands of a husband or boyfriend. ${ }^{95}$ Violence against young women is also increasing. In 1990 , the Senate found that young women were being attacked at twice the rate they had been in 1974, while young men were being attacked twelve percent less frequently. ${ }^{96}$

\section{Congress Found That Either State Law Did Not Address the Problem or Remedies Were Inadequate}

The Senate concluded that there were inadequate remedies at state and local law. The Senate Report cites seventeen studies commissioned by various state court task forces and bar associations that

${ }^{89}$ S. REP. NO. 103-138, at 38 (1993). In 1994, there was one rape for every 270 women. See generally BUREAU OF JUSTICE STATISTICS, U.S. DEP'T OF JUSTICE, FEMALE VICTIMS OF VIOLENT CRIME (1996).

${ }^{90}$ See S. REP. No. 101-545, at 30 (1990).

${ }^{91}$ See Siegel, supra note 9, at 2172 (citing BUREAU OF JUSTICE STATISTICS, U.S. DEP'T OF JUSTICE, VIOLENCE AGAINST WOMEN: ESTIMATES FROM THE REDESIGNED SURVEY 1 (1995) [hereinafter ESTIMATES]); see also BUREAU OF JUSTICE STATISTICS, U.S. DEP'T OF JUSTICE, SEX Differences IN Violent Victimization, 1994, at 5 (1997) ("Among female victims, friends or acquaintances committed $40 \%$ of the rapes and sexual assaults; strangers, $32 \%$; and intimates, $24 \% . "$ ).

${ }^{92}$ S. REP. NO. 101-545, at 37.

${ }^{93}$ S. REP. NO. 102-197, at 38 (1991); see S. REP. No. 103-138, at 41 (same).

${ }^{94}$ See S. REP. No. 103-138, at 38.

${ }^{95}$ Id. at 41; see also ESTIMATES, supra note 91 , at 4 ("In 1992 approximately $28 \%$ of female victims of homicide (1,414 women) were known to have been killed by their husband, ex-husband, or boyfriend.").

${ }^{96}$ See S. REP. No. 101-545, at 31; see also ESTIMATES, supra note 91, at 4 ("Women age 12 to 18 were more likely than women older than 18 to report violence against them by friends or acquaintances."). 
found that crimes against women are treated less seriously than other violent crimes. ${ }^{97}$ In addition, when defendants do get convicted, their sentences are short. The Senate found that almost twenty-five percent of convicted rapists served no time and that an additional twentyfive percent were sentenced to "local jails where the average sentence is 11 months." ${ }^{, 1}$ In many cases, a woman who has been raped or assaulted receives no compensation for her injuries. Suits for intentional torts within marriage are barred to some degree in nine states. ${ }^{99}$

\section{Congress Found That There Was Uneven Enforcement of Existing Laws}

The Senate concluded that "crimes against women are often treated differently and less seriously than other crimes. Police may refuse to take reports; prosecutors may encourage defendants to plead to minor offenses; judges may rule against victims on evidentiary matters ...."100 In the case of sexual assault, "[a]t every step of the way, the criminal justice system poses significant hurdles for victims."

The Senate found that police are not doing their job when it comes to protecting women from violence. The Senate Report cites a 1989 study done in Washington, D.C., which demonstrated that police failed to arrest batterers in "over 85 percent of the family violence cases where a woman was found bleeding from wounds." ${ }^{102}$ Many other studies found similar results-demonstrating that police fail to answer calls, write reports, and make arrests. ${ }^{103}$

A woman's difficulties do not end once an arrest is made. The Senate cited several state studies documenting the effects on women

${ }^{97}$ See S. REP. NO. 103-138, at $49 \mathrm{n} .52$ (listing studies that have "concluded that crimes disproportionately affecting women are often treated less seriously than comparable crimes affecting men").

Id. at 38 .

${ }^{99}$ See Siegel, supra note 9, at 2163 n.163 (describing how different states treat the doctrine of interspousal tort immunity).

${ }^{100}$ S. REP. NO. 103-138, at 42.

101 Id.

${ }^{102} I d$. at 41 .

${ }^{103}$ See Amy Eppler, Battered Women and the Equal Protection Clause: Will the Constitution Help Them When the Police Won't?, 95 YALE L.J. 788, 788 n.3 (1986) (providing a list of relevant studies); see also Panel Discussion, supra note 33, at $403 \mathrm{n} .17$ (statement of Betty Levinson) (citing a study that found that only $25 \%$ to $30 \%$ of domestic violence calls to police in New York City resulted in the written reports that are mandated by law). 
of gender bias in the courts. In one case, a judge in Georgia "reported that one of his colleagues, in a case of repeated domestic abuse, 'mocked'... the victim and 'led the courtroom in laughter as the woman left ....' Subsequently, the woman was killed by her estranged husband." 104 In another case, a Maryland judge "stated in court that he didn't believe anything that the abuse victim was saying 'because I don't believe anything like this could happen to me." 105 In Connecticut, a prosecutor demanded of a fifteen-year-old rape victim in court: "Come on, you can tell me. You're probably just worried that your boyfriend got you pregnant, right? Isn't that why you're saying he raped you?"106 In Florida, a state judge jailed a rape victim when the victim recanted her prior accusation because she felt pressure from her ex-boyfriend and his family who were in the courtroom. ${ }^{107}$

At the 1990 hearings, Sarah M. Buel, an assistant district attorney from Massachusetts, testified about the difficulty of prosecuting and obtaining a conviction in a rape case in which the parties had a relationship:

I can try two cases back-to-back. If it is a stranger assault, I have no trouble getting the maximum, absolutely none. I get the married couple in there and the judge wants to talk about, "Now, are you sure you don't want to go to marriage counseling ..." and just complete denial about her danger. I am terrified for her life, and the judge wants to talk about this illusion of mom, pop, bud, sis, and dog Spot ....

Buel stated that in a drug case, if the perpetrator goes to the home of a witness and makes threats before trial, an arrest or an added offense often results. In a domestic violence case, a perpetrator's threats to the victim before trial often go unpunished. ${ }^{109}$ The civil rights remedy of the VAWA was Congress's response to the evidence it collected concerning the seriousness of violence against women, the lack of or inadequacy of existing state remedies, and the unequal enforcement of the remedies that did exist.

104 S. REP. No. 102-197, at 34 (1991).

${ }^{105} I d$.

${ }^{106} I d$.

${ }^{107}$ See Christina Cheakalos, "I Wanted Her to Think... and Tell the Truth," MIAMI HERALD, July 31, 1989, at $1 \mathrm{~A}$ (recounting how the judge put the woman in jail for a night).

${ }_{103}$ Nourse, supra note 2, at 11 (citing Women and Violence: Hearing Before the Senate Comm. on the Judiciary, 101st Cong. 163-64 (1990) (testimony of Sarah M. Buel)).

${ }^{109}$ See id. at 10 n.57. 


\section{E. Congressional Authority to Enact the VAWA}

Congress purported to act pursuant to its powers under the Commerce Clause and Section 5 of the Fourteenth Amendment in enacting the VAWA civil rights remedy. ${ }^{110}$

\section{The Commerce Clause}

Congress claimed that the Commerce Clause provided one source of authority to enact the VAWA civil rights remedy. The VAWA was passed before the landmark 1995 Supreme Court decision in United States v. Lopez ${ }^{111}$-the first time in nearly sixty years that the Court rejected a congressional assertion of power under the Commerce Clause. ${ }^{112}$ Therefore, the VAWA's legislative history reflects a preLopez understanding of the Commerce Clause power. ${ }^{113}$ Namely, " $\mathrm{t}]$ he court must defer to a congressional finding that a regulated activity affects interstate commerce, if there is any rational basis for such a finding." 114

During the VAWA hearings, Congress heard a significant amount of testimony regarding the link between gender discrimination in the form of violence and interstate commerce. In response to this testimony, Congress found, for example, that "crimes of violence motivated by gender have a substantial adverse effect on interstate commerce, by deterring potential victims from traveling interstate, from engaging in employment in interstate business, and from transacting business ... in interstate commerce." The Senate found that violence against some women "restricts movement [and] reduces employment opportunities"

${ }^{110}$ See S. REP. No. 103-138, at 54-55 (1993); S. REP. NO. 102-197, at 52-54.

${ }^{111} 514$ U.S. 549, 567-68 (1995) (holding that the Gun-Free School Zones Act of 1990 exceeded Congress's Commerce Clause authority).

${ }^{112}$ See Anisimov v. Lake, 982 F. Supp. 531, 534 (N.D. Ill. 1997) (“Congress's freedom under the Commerce Clause was restricted for the first time in almost sixty years by the Supreme Court in [Lopez].").

113 See Nourse, supra note 2, at 18 (describing testimony of experts claiming that the VAWA would "easily pass constitutional scrutiny"); see, e.g., Violence Against Women: Victims of the System: Hearing on S. 15 Before the Senate Comm. on the Judiciary, 102d Cong. 113-17 (1991) [hereinafter Hearing] (statement of Cass Sunstein, Professor of Law, University of Chicago Law School).

${ }^{114}$ Hodel v. Virginia Surface Mining \& Reclamation Ass'n, 452 U.S. 264, 276 (1981) (emphasis added). Many courts are still applying the Hodel test post-Lopez. See cases cited infra note 260 .

${ }^{115}$ H.R. REP. NO. 103-711, at 385 (1994).

${ }^{116}$ S. REP. No. 103-138, at 54 (1993). 
health expenditures, and reduces consumer spending." ${ }^{\text {"17 }}$ The Senate Report cited a study that found that nearly fifty percent of rape victims quit or lost their jobs after the rape. ${ }^{118}$ In addition, the Senate, citing statistics indicating that homicide is the number one cause of death for women who die on the job, ${ }^{119}$ determined that fear of discriminatory violence "affects the economy because it deters women from taking jobs in certain areas or at certain hours that pose a significant risk of such violence.,"120

Congress concluded that its findings were sufficient to meet "the modest threshold required by the Commerce Clause." Lopez later raised this threshold. The effect of Lopez on the VAWA is discussed below in Part II.A.4.

\section{Section 5 of the Fourteenth Amendment}

Congress also invoked its power under Section 5 of the Fourteenth Amendment as authority for the civil rights remedy. ${ }^{122}$ The Senate Judiciary Committee declared that "gender-motivated crimes ... threaten women's equal protection of the laws." ${ }^{123}$ As support for congressional authority to enact a private remedy to address public discrimination, the Senate Report cited Katzenbach v. Morgan ${ }^{124}$ and District of Columbia $v$. Carter. ${ }^{125}$ The Senate Report proclaimed

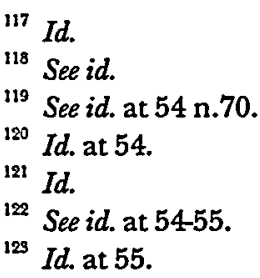

${ }^{124} 384$ U.S. 641 (1966). Katzenbach held that section $4(\mathrm{e})$ of the Voting Rights Act is within Congress's power under Section 5 of the 14th Amendment. See id. at 668. According to Professor Cass Sunstein, there are two possible interpretations of Katzenbach that would support Congress's power to enact the VAWA civil rights remedy. The radical view, never accepted by a clear majority of the Court, is that "Congress could actually conclude that a practice violated the fourteenth amendment even if the Court disagreed; and having so concluded,.... Congress can actually define the content of the equal protection clause." Hearing, supra note 113, at 118 (statement of Professor Cass Sunstein). The less sweeping interpretation, as modified by City of Rome v. United States, 446 U.S. 156 (1980), is that Congress may "provide remedies" for 14th Amendment violations even when the remedies also reach activities that "do not violate the Constitution." Hearing, supra note 113, at 119 (statement of Professor Cass Sunstein).

${ }^{125} 409$ U.S. $418,424 \mathrm{n} .8$ (1973) ("This is not to say, of course, that Congress may not proscribe purely private conduct under $\S$ five of the Fourteenth Amendment."). For another view of Congress's authority to reach private action, see United Brotherhood 
that these cases established that "[w] only covers actions by the States, Congress's power to enforce the amendment includes the power to create a private remedy as the most effective means to fight public discrimination." ${ }^{126}$ According to the Katzenbach theory, Congress's target is the equal protection violation wrought by state and local governments that refuse to treat violence against women the same way that they treat other crimes of violence. ${ }^{127}$ The civil rights remedy is the vehicle for enforcement of deprivation of equal protection by gender-motivated crimes. Professor Cass Sunstein testified before Congress that the Katzenbach theory makes irrelevant the issue of whether Congress may address private action via the Fourteenth Amendment. ${ }^{128}$

\section{CHALlENGES TO THE CIVIL RightS REMEDY FOR VIOLENCE AGAINST WOMEN: STATE ACTION, PRIVACY, FEDERALISM, AND LOPEZ}

The VAWA civil rights remedy has been extremely controversial. ${ }^{129}$ From its introduction to congressional debate to constitutional challenges in district courts, arguments opposing the civil rights remedy have fallen into three categories: state action, privacy, and federalism. After Lopez, a fourth objection arose: the VAWA oversteps the reestablished boundaries of Commerce Clause power.

of Carpenters, Local 610 v. Scott, 463 U.S. 825, 842 (1983) (Blackmun, J., dissenting) ("Congress had authority to reach private conduct by virtue of its power to protect the rights of national citizenship.").

${ }^{126}$ S. REP. NO. 103-138, at 55 n.72.

127 Professor Cass Sunstein described the theory as follows:

Congress could say that it is seeking to remedy what would clearly be a constitutional violation under the Supreme Court's own decisions. Such a violation consists of bias or discrimination in the administration of the criminal justice system-in the form of a refusal to deal adequately with crimes against women, in part because the victims in the relevant cases are women.

Hearing, supra note 113, at 121 (statement of Professor Cass Sunstein); see also Robin West, Toward an Abolitionist Interpretation of the Fourteenth Amendment, 94 W. VA. L. REV. $111,146-47$ (1991) (arguing that one of the fundamental rights of national citizenship is the right to be free from private violence, and that a state breaches its equal protection guarantee when it fails to protect victims from private violence).

${ }^{128}$ Sunstein stated:

Congress is responding to an equal protection problem in the administration of state and local law by state and local governmental authorities. It is not responding to private acts at all-no more than the equal protection clause itself does so by requiring states to protect blacks as well as whites from private violence.

Hearing, supra note 113, at 122-23 (statement of Professor Cass Sunstein).

129 See supra note 33 and accompanying text. 
To date, there have been six reported ${ }^{130}$ constitutional challenges to the VAWA civil rights remedy: Doe v. Doe, ${ }^{131}$ Brzonkala v. Virginia Polytechnic E State University, ${ }^{132}$ Doe v. Hartz, ${ }^{133}$ Seaton v. Seaton, ${ }^{134}$ Anisimov v. Lake, ${ }^{135}$ and Crisonino v. New York City Housing Authority. ${ }^{136}$ In each case, the defendant(s) challenged Congress's power to enact the civil rights remedy under the Commerce Clause and/or Section 5 of the Fourteenth Amendment. ${ }^{137}$

\section{A. Arguments Against the Civil Rights Remedy}

\section{State Action Arguments}

There are legitimate state action arguments against the civil rights remedy notwithstanding Congress's claim that it had authority under Section $\mathbf{5}$ of the Fourteenth Amendment to enact a private remedy for public discrimination. In recent years, the Supreme Court steadfastly has supported the notion that the Fourteenth Amendment requires affirmative state action. ${ }^{138}$ This position is illustrated most clearly in DeShaney v. Winnebago County Department of Social Services, in which the Court held that Wisconsin's failure to intervene in a case of known and ongoing child abuse was not a violation of the child's liberty under the Due Process Clause of the Fourteenth Amendment. ${ }^{139}$ Although DeShaney involved the Due Process Clause and the VAWA relies on the Equal Protection Clause, the Court might approach a

${ }^{150}$ See also Mattison v. Click Corp. of Am., Civ. A. No. 97-CV-2736, 1998 WL 32597 (E.D. Pa. Jan. 27, 1998) (mem.) (upholding the VAWA and citing the cases discussed in this section).

131929 F. Supp. 608 (D. Conn. 1996).

${ }^{132} 935$ F. Supp. 779 (W.D. Va. 1996), rev'd, 132 F.3d 949 (4th Cir. 1997), reh'g en banc granted and opinion vacated, WASH. POST, Feb. 8, 1998, at B3 (4th Cir. Feb. 5, 1998).

${ }^{193} 970$ F. Supp. 1375 (N.D. Iowa 1997), rev'd in part and vacated in part on other grounds, 134 F.3d 1339 (8th Cir. 1998).

${ }^{134} 971$ F. Supp. 1188 (E.D. Tenn. 1997). The Seaton case was later dismissed without prejudice before trial when the plaintiffs failed to file a pretrial order. See Randy Kenner, Judge Dismisses Seaton Suit, Cites Flouted Timeliness Rules, KNOXVLLE NEwSSENTINEL, Jan. 13, 1998, at A4, available in 1998 WL 8570550.

${ }^{135} 982$ F. Supp. 531 (N.D. Ill. 1997).

${ }^{156} 985$ F. Supp. 385 (S.D.N.Y. 1997).

${ }^{137}$ Congress explicitly predicated the passage of the VAWA on its 14th Amendment and Commerce Clause powers. See 42 U.S.C. $\$ 13981$ (a) (1994); S. REP. NO. $102-$ 197, at 52 (1991).

${ }^{\text {is }}$ See The Civil Rights Cases, 109 U.S. 3, 13 (1883) (establishing that the 14th Amendment requires state action).

${ }^{199} 489$ U.S. 189, 195 (1989). 
Fourteenth Amendment challenge to the VAWA in a similar manner. ${ }^{140}$

The facts in DeShaney are extreme. Four-year-old Joshua DeShaney arrived in an emergency room with suspicious bruises. The Wisconsin Department of Social Services took Joshua into temporary custody, but later returned him to his father. Over the course of the next six months, Joshua returned to the emergency room twice. In addition, a caseworker visited his home on multiple occasions, noting bruises and marks on his body. The State nevertheless took no further action. Ultimately, Mr. DeShaney beat Joshua's head so severely that the child fell into a coma, and was left permanently and severely retarded. ${ }^{14}$

In denying recovery to Joshua, the Court explained that the Due Process Clause does not "require[] the State to protect the life, liberty, and property of its citizens against invasions by private actors." ${ }^{142}$ The Court further cautioned:

[I] $\mathrm{t}$ is well to remember once again that the harm was inflicted not by the State of Wisconsin, but by Joshua's father. The most that can be said of the state functionaries in this case is that they stood by and did nothing when suspicious circumstances dictated a more active role for them ....

The people of Wisconsin.... should not have [liability] thrust upon them by this Court's expansion of the Due Process Clause of the Fourteenth Amendment. ${ }^{143}$

With this language, the Court limited the scope of the state action doctrine for Fourteenth Amendment purposes to affirmative acts by state actors, irrespective of how Wisconsin's failure to act left Joshua's father unhindered to commit violence against his son. ${ }^{144}$ The Court refused to acknowledge that the State's failure to intervene allowed

${ }^{140}$ See infra text accompanying notes $146-47$ (describing the effect of DeShaney on $\S 1983$ cases brought on equal protection grounds against police departments for their failure to protect victims of domestic violence).

${ }^{141}$ See DeShaney, 489 U.S. at 191-93 (detailing the tragic sequence of events).

142 Id. at 195.

${ }^{143}$ Id. at 203 (emphasis added). Compare this language with Judge Kiser's language in Brzonkala: "Certainly the state is not responsible in any relevant sense for individuals who commit violent crimes against women." Brzonkala v. Virginia Polytechnic \& State Univ., 935 F. Supp. 779, 797 (W.D. Va. 1996), rev'd, 132 F.3d 949 (4th Cir. 1997), reh'g en banc granted and opinion vacated, WASH. POST, Feb. 8, 1998, at B3 (4th Cir. Feb. 5, 1998).

144 See Martha Minow, Words and the Door to the Land of Change: Law, Language, and Family Violence, 43 VAND. L. REV. 1665, 1668-70 (1990) (describing the dissent's position and arguing that in DeShaney, the State committed "violations through complicity"). 
Mr. DeShaney to beat Joshua nearly to death. ${ }^{145}$ Given its position that state action must be affirmative, it seems unlikely that the Court would uphold, under a Fourteenth Amendment theory, a statute like the VAWA that provides a remedy for privately inflicted violence.

Indeed, since DeShaney, it has become increasingly difficult for survivors of domestic violence to sue local governments under $\S 1983^{146}$ for failure to protect them from battering. ${ }^{147}$ Lower courts even have held that equal protection claims, in which, for example, a local police department has a different arrest policy for family violence and street violence, are barred by DeShaney. For example, in McKee v. City of Rockwall, the Fifth Circuit relied on DeShaney to deny recovery on equal protection grounds to a woman whose boyfriend injured her after the police refused to arrest him. ${ }^{148}$

\section{Marital Privacy Arguments}

The ideal of marital or familial privacy forms a conceptual bulwark against a legal remedy for gender-motivated violence when the parties share a familial or intimate relationship. The VAWA covers a full spectrum of violence against women, ranging from one-time stranger assaults, to date rape, to child sexual abuse lasting one year, to familial violence lasting over two decades. ${ }^{149}$ The VAWA's goal is to counteract a legal system that refused to interfere with violence occurring within the private familial sphere. The statute was designed to help victims combat:

145 See id. at 1666 ("Joshua's father's violence put Joshua into a coma and left him paralyzed and without the functioning of half of his brain. The doctors found pools of rotted blood inside his brain as the result of months of bleeding from repeated assault.").

${ }^{146}$ See 42 U.S.C. $\$ 1983$ (1994) (providing a civil rights remedy when a person's constitutional or statutory rights have been violated by government officials).

117 See Elizabeth M. Schneider, The Violence of Privay, 23 CONN. L. REV. 973, 986 n.56 (1991) ("Courts are rejecting [\$ 1983] substantive due process claims, which are typically based on the alleged existence of a 'special relationship' between the victims and the State ... as incompatible with DeShaney."); cf. Laura S. Harper, Note, Battered Women Suing Police for Failure to Intervene: Viable Legal Avenues After DeShaney v. Winnebago County Department of Social Services, 75 CORNELI L. REV. 1393, 1393-94 (1990) (arguing that an equal protection claim, even with the higher standard of discriminatory intent, may be more fruitful than a due process claim).

14877 F.2d 409, 413 (5th Cir. 1989) (refusing to "permit plaintiffs to circumvent the rule of DeShaney by converting every Due Process claim into an Equal Protection claim"); Harper, supra note 147, at 1411-13 (discussing McKee in reference to the DeShaney decision).

149 See supra note 36 and accompanying text (defining a crime of violence motivated by gender). 
[a] law veiled by the idea of the relationship, a law that perceived "marital disputes" where there were felonies; that refused to see force as force as long as it was tied to an acquaintance; that believed that there was something "personal" about rape when perpetrated by a husband; that said that violence was chosen by choosing a relationship. ${ }^{150}$

Accordingly, the VAWA represents a direct threat to a system of law bounded by privacy because it declares that private violence is a public act: gender discrimination. ${ }^{151}$

Throughout most of the twentieth century, violence against women inflicted by their husbands, including physical assault and rape, has been labeled "private." The perpetrators of such violence have been granted complete or partial immunity from prosecution. ${ }^{152}$ Marital privacy has provided a justification for not arresting, for not criminally prosecuting, and for reducing the punishments of men who beat, maim, assault, and rape their intimate partners. ${ }^{153}$ For example, the current version of the Model Penal Code still contains a marital rape exemption because, according to its drafters, "the law of rape, if applied to spouses, would thrust the prospect of criminal sanctions into the ongoing process of adjustment in the marital relationship." "154

Feminist scholars criticize this conception of privacy, arguing that, although the distinctions between the private and the public, or between the home and the marketplace, appear "natural," they are

${ }^{150}$ Nourse, supra note 2 , at $3-4$.

${ }^{151}$ See supra notes $47-48$ and accompanying text; see also S. REP. No. 102-197, at 37 (1991). The Senate report stated:

Our country has an unfortunate blind spot when it comes to certain crimes against women. Historically, crimes against women have been perceived as anything but crime-as a "family" problem, as a "private" matter, as sexual "miscommunication." That tradition of ambivalence has led to oxymoronic labels such as "date rape," and "domestic violence," both of which suggest that the violence described is somehow less violent or less harmful or less serious if it takes place in a social setting or at home. Until we name a problem, we cannot hope to see it for what it is. And until we name all violence against women as crime, it will be seen neither as violence nor as crime.

Id.

${ }^{152}$ See Schneider, supra note 147 , at 974 ("The concept of freedom from state intrusion into the marital bedroom takes on a different meaning when it is violence that goes on in the marital bedroom. The concept of marital privacy, established as a constitutional principal in Griswold, historically has been the key ideological rationale for state refusal to intervene to protect battered women within ongoing intimate relationships." (citations omitted)).

${ }^{153}$ See Siegel, supra note 9 , at $2170-74$ (detailing the relationship between privacy and the legal response to violence against women).

${ }^{154}$ MODEL PENAL CODE $§ 213.1 \mathrm{cmt}$. 8(c) (1980). 
really just normative conclusions. They claim the choice between what is private and what is public is a political one, serving only to protect male privilege. ${ }^{155}$ When the State fails to arrest or punish the perpetrator of a violent crime against a woman, the offender is empowered by implicit state sanction to continue his abusive behavior. The victim is left with only extralegal options. ${ }^{156}$ Thus, the doctrine of privacy removes the law from a woman's reach and her home. ${ }^{157}$

In her work on the marital rape exemption, Robin West explains the differences between feminist and judicial constructs of privacy as follows:

The obstacles to women's equal participation in public life ... are so thoroughly ingrained in our societal habits, institutions, and thought patterns that they appear not as obstacles to equality, but as the essence of private life.... The bottom line is that the same reality experienced by the raped wife as a daily ritual of violence, abuse, and horror strikes the feminist as unconscionable state passivity in the face of private subordination and strikes the feminist lawyer as the denial of equal protection. But it conceivably appears to the Court as a[n] "important" or "compelling" state interest in marital privacy, marital harmony, and spousal reconciliation.

${ }^{155}$ See Schneider, supra note 147, at 977 ("[S]elective application of law invokes 'privacy' as a rationale for immunity in order to protect male domination."). For a parallel critique in the context of racial discrimination, see Neil Gotanda, $A$ Critique of "Our Constitution is Color-Blind," 44 STAN. L. REv. 1, 13-14 (1991) ("The state action framework supports the supremacy of ensconced interests-usually white-by placing the burden on the person challenging the 'common sense' public-private distinctions....").

${ }^{156}$ See Schneider, supra note 147, at 977 ("[W] battered woman's call for assistance, or when a civil court refuses to evict her assailant, the woman is relegated to self-help ...."). The impact of societal choices favoring males is demonstrated in three telling stories described by Elizabeth Schneider. In each case, a pregnant woman who sought help because her partner had abused her ended up being charged with criminal child abuse for alcohol or substance abuse during pregnancy. The batterers were never prosecuted. Seeid. at 977 n.17.

${ }^{157}$ See Taub \& Schneider, supra note 11, at 156 ("The message of women's inferiority is compounded by the totality of the law's absence from the private realm. In our society, law is for business and other important things. The fact that the law in general has so little bearing on women's day-to-day concerns reflects and underscores their insignificance.").

${ }_{133}$ West, supra note 51 , at 67 . Schneider also discusses how the concept of privacy sometimes fosters violence against women:

Privacy says that violence against women is immune from sanction, that it is permitted, acceptable and part of the basic fabric of American family life. Privacy says that what goes on in the violent relationship should not be the subject of state or community intervention. Privacy says that it is an individ- 
Adding to the apparent logic of the privacy doctrine are its deep historical roots. Reva Siegel argues that the current regime of "privacy" resulted from the breakdown of the prior legal system of common-law marriage known as coverture. ${ }^{159}$ Under coverture, a woman merged with her husband upon marriage and therefore legally disappeared; by law, the husband "acquired rights to his wife's person, the value of her paid and unpaid labor, and most property she brought into the marriage." Wives were unable to sue in their own names, husbands were answerable for their wives' torts, and, as a result, husbands gained the right to chastise their wives. ${ }^{161}$ Siegel argues that the characterization of wife abuse as "private" is simply a "preservation through transformation"162 of the common-law marital prerogative of chastisement. When the doctrine of chastisement was repudiated during the Reconstruction Era, judges began to substitute marital privacy for the right of chastisement, reaching identical results in the few wife abuse cases that were even brought to court. ${ }^{163}$ Siegel argues that the codification of privacy reached its apotheosis in the twentieth century as wife abuse was decriminalized by channeling domestic cases through family courts that emphasize reconciliation over criminal punishment. ${ }^{164}$ Siegel's thesis is also reflected in the other original common-law incidents that have been reestablished via privacy: interspousal immunity for torts, refusal to honor premarital contracts other than those involving real property (inability to make or enforce contracts), and support agreements that do not reflect the

ual, and not a systemic problem. Privacy operates as a mask for inequality, protecting male violence against women.

Schneider, supra note 147 , at $984-85$.

${ }^{159}$ See Siegel, supra note 9, at 2119, 2121-74 (" [A]s the nineteenth-century feminist movement protested a husband's marital prerogatives [under coverture], the movement helped bring about the repudiation of chastisement doctrine; but, in so doing, the movement also precipitated changes in the regulation of marital violence that 'modernized' this body of ... law.").

${ }_{160} I d$. at 2122.

${ }^{161}$ See id. at 2123-25 (summarizing pre-late-19th-century legal relationships between husbands and wives).

${ }_{162} I d$. at 2119 . In defining "preservation through transformation," Siegel explains: "When the legitimacy of a status regime is successfully contested, lawmakers and jurists will both cede and defend status privileges-gradually relinquishing the original rules and justificatory rhetoric of the contested regime and finding new rules and reasons to protect such status privileges as they choose to defend ...." Id.

${ }^{163}$ See id. at 2129-30 ("[I]t would be misleading to look to the repudiation of chastisement doctrine as an indicator of how the legal system responded to marital violence.").

${ }^{164}$ See $i d$. at 2170 (" $[\mathrm{B}] \mathrm{y}$ the $1920 \mathrm{~s}$, most major cities had [domestic relations] courts."). 
value of domestic work added to the partnership by the woman (reflecting the common-law idea that the man was entitled to his wife's domestic services). ${ }^{165}$

Privacy no longer functions as an absolute bar to justice for women who are harmed by their fathers, brothers, husbands, and lovers. The women's movement, the battered women's movement, and the rapecrisis movement have made violence against women more public. Many states have tempered the total marital rape exemption, ${ }^{166}$ enacted mandatory arrest policies for domestic violence cases, created civil protection order procedures for victims, increased criminal prosecutions for domestic violence, and funded shelters. ${ }^{167}$ The VAWA represents an important shift in paradigm at the congressional level-from private violence to public gender discrimination. ${ }^{163}$ The newness and incompleteness of that shift, however, leaves the VAWA vulnerable to attack under the prior paradigm of privacy; it may also pave the way for an interpretation of the VAWA that would yield the same result as under the prior regime. ${ }^{169}$

\section{Federalism Arguments}

The federal and state judiciaries actively opposed the earliest versions of the VAWA civil rights remedy, couching their objections in terms of federalism concerns and already overcrowded dockets. ${ }^{170}$ In 1991, the Conference of Chief Justices of State Supreme Courts opposed the proposed civil rights remedy because it would cause "state-

${ }^{165}$ See Taub \& Schneider, supra note 11, at 155 (noting that the "same result was previously justified by legal fictions, such as the woman's civil death on marriage").

ico See supra text accompanying notes 51-55.

${ }^{167}$ See Schneider, supra note 147, at 980-86 (detailing recent beneficial developments for victims of domestic violence).

${ }^{168}$ See Nourse, supra note 2, at 3-5 (drawing a comparison with the paradigm shift in race relations); Siegel, supra note 9, at 2197 (stating that the civil rights remedy "analyzed violence against women as a form of sex discrimination").

${ }^{169}$ See supra note 162 (explaining Siegel's concept of "preservation through transformation").

${ }^{170}$ Although many early objections were met by changes in the wording of the bill, see Nourse, supra note 2, at 27-33 (detailing changes in the 1993 version of the VAWA, including procedural changes made to counter the federalism objections of the federal and state judiciaries), it is instructive to repeat the objections here because of their logical resonance and the possibility that they could resurface on appeal. 
federal jurisdictional problems and disruptions in the processing of domestic relations cases in state courts." ${ }^{\text {"71 }}$

The Judicial Conference of the United States opposed the remedy for fear of an onslaught of cases. ${ }^{172}$ In his 1991 year-end report, Chief Justice William Rehnquist singled out the VAWA civil rights remedy as a new, unwarranted burden on the federal judiciary. ${ }^{173}$ The Chief Justice presented his objections to the VAWA by analogizing the federal judiciary to a water-starved western city grown beyond its resources and urging "self-restraint in adding new federal causes of action." The Chief Justice continued: "New additions should not be made unless critical to meeting important national interests which cannot otherwise be satisfactorily addressed through nonjudicial forums, alternative dispute resolution techniques, or the state courts." ${ }^{175} \mathrm{He}$ identified the VAWA as a "new private right of action so sweeping, that it could involve the federal courts in a whole host of domestic relations disputes."

Federalism objections to the VAWA are fueled by the ideology of privacy $^{177}$ and draw legitimacy from a historic "domestic relations exception" that excludes alimony, divorce, and child custody cases from diversity jurisdiction. ${ }^{178}$ According to Professor Naomi Cahn, the domestic relations exception is itself a product of the ideology of privacy - of "the outmoded dichotomy between a public sphere (the marketplace, federal courts) and a private sphere (the family, the state courts)."179

${ }^{171}$ See Siegel, supra note 9, at 2198 (quoting Crimes of Violence Motivated by Gender: Hearing Before the Subcomm. on Civil and Constitutional Rights of the House Comm. on the Judiciary, 103d Cong., 1st. Sess. 80 (1993)).

${ }^{172}$ See Siegel, supra note 9, at 2198.

173 See William H. Rehnquist, 1991 Year-End Report on the Federal Judiciary, 138 CONG. REC. S443, S444 (daily ed. Jan. 27, 1992).

${ }^{174}$ Id. at S443.

175 Id.

176 Id.

177 See Siegel, supra note 9, at 2201 ("Federalism objections to the civil rights remedy acquire persuasive power as they draw on the traditional modes of reasoning about intimate assault.").

${ }^{178}$ See Naomi R. Cahn, Family Law, Federalism, and the Federal Courts, 79 IOWA L. REV. 1073, 1073 (1994) (" [T] here has developed both a legislative and judge-made Domestic Relations Exception, precluding federal courts from hearing divorce, alimony, and child custody cases." (emphasis added)). The domestic relations exception does not preclude federal courts from hearing all "diversity cases that could be deemed domestic relations cases. When such cases involve other areas of the law, such as tort or contract, the cases will proceed." Id. at 1075.

${ }^{179}$ Id. at 1101 . Cahn continues: 
Cahn argues that the domestic relations exception enables federal courts to invoke "federalism" to screen out cases requiring a court to examine relationships between family members. ${ }^{180}$ Cahn maintains that although federal courts routinely hear cases in which women challenge their role in the public/marketplace sphere, such as Title VII cases, the domestic relations exception allows federal courts to avoid cases in which women challenge their role in the private/family sphere. ${ }^{181}$

According to Cahn, the federalism objections to the VAWA are simply an extension of this historical discrimination against cases involving intrafamily relationships, and the "overcrowding" concern is a value judgment on the importance of violence against women. Cahn argues:

[T] he traditional aversion to family law appears to... explain the federal judiciary's reaction to the VAWA. The notion that federal courts should not overload their schedules with domestic relations cases implies that these cases are not as important as others which should ... fill up the ... dockets.... The concern is not with overcrowding the courts, but with the types of cases that the courts might be forced to hear. ${ }^{182}$

Similarly, Reva Siegel argues that federalism objections to the VAWA result from jurists looking at a civil rights remedy that names violence against women as gender discrimination through the old,

While the "separate spheres" ideology was explicit in the late nineteenth century, it is now an implicit underlying theme that permeates the Court's family law decisions. There are two aspects to the Court's public/private dichotomy in family law: one between the states, which provide public regulation, and the family, which, notwithstanding public regulation, still belongs to the private sphere; and a second between the federal and state courts. The federal courts generally respect state interests and regulation concerning dependent intrafamily relationships, but they do not defer to state law when an examination of such relationships is not central.

Id. at 1101-02.

${ }^{180}$ See id. at 1101. According to Cahn:

When a domestic relations case looks like another case over which federal courts typically exercise diversity jurisdiction, such as a tort or contract case, and does not involve a determination of the ongoing nature of family relationships, then the Court will proceed.... When a domestic relations case requires an examination of the interdependencies within the family, or of ongoId. ing family relationships, the Court relegates the case to the state courts.

${ }^{182}$ See id. at 1100 ("In the private sphere of the family, the Court does not examine women's traditional role, while in the public sphere of the workplace, women can successfully challenge the status quo.").

182 Id. at 1110. 
flawed lens of marital privacy. "Federalism" is merely the name given the confusion caused by the paradigm shift:

In [federalism] objections the issue of gender bias that prompted VAWA's enactment recedes from view, and sexualized assault appears as a problem concerning "family matters." ... It is only by virtue of this historical tradition that significant audiences of lawmakers and jurists find it at all persuasive to characterize acts of rape or battery as matters of "domestic relations" law, or the stuff of "acrimonious" "divorce negotiations," or as "sensitive policy issue [s]," or "matters traditionally entrusted to the states." In short, it is because critics of the civil rights remedy are still reasoning within the common law tradition the statue seeks to disestablish that they can characterize VAWA as intruding in regulatory domains that are not properly of federal concern. ${ }^{18}$

Given judges' training in the doctrine of marital privacy and the consensus that family law is exempt from federal purview, it is hardly surprising that some judges object to the VAWA. The VAWA directly challenges the status quo of marital privacy and a federalism that accords secondary status to women's issues.

\section{The Effect of United States $v$. Lopez on the VAWA}

In United States v. Lopez, the Supreme Court reasserted the longignored "outer limits" of Congress's power under the Commerce Clause. ${ }^{184}$ Thus, Lopez rendered the civil rights remedy vulnerable to attack on the ground that it is an overextension of Congress's commerce power. ${ }^{185}$ For the purposes of this Comment, I will sketch the outlines of the Commerce Clause question after Lopez only to the extent that the uncertainty engendered by Lopez affects the analysis of the VAWA's constitutionality under the Commerce Clause. ${ }^{186}$

In Lopez, the Court invalidated the Gun-Free School Zones Act ("the GFSZA"), ${ }^{187}$ which made it a federal criminal offense to possess

${ }^{183}$ Siegel, supra note 9, at 2201-02 (second alteration in original) (footnotes omitted).

${ }^{184} 514$ U.S. 549, 557 (1995).

${ }^{185}$ For example, defendants in each district court case challenged the VAWA on Commerce Clause theories. See infra Part II.B.

${ }^{186}$ For a comprehensive treatment of the effect of Lopez on the VAWA concluding that the VAWA is a constitutional exercise of Congress's commerce power, see Kerrie E. Maloney, Note, Gender-Motivated Violence and the Commerce Clause: The Civil Rights Provision of the Violence Against Women Act After Lopez, 96 CoLuM. L. REV. 1876 (1996); see also Nourse, supra note 2, at 18-23 (discussing ramifications of Lopez).

${ }^{187} 18$ U.S.C. $\$ 922(q)(1)(A)(1994)$. 
a gun in a school zone. ${ }^{188}$ The Court emphasized that Congress may only regulate "(1) the use of channels of interstate commerce, (2) the instrumentalities of interstate commerce, or persons or things in interstate commerce, and (3) those activities that substantially affect interstate commerce." ${ }^{189}$ The Lopez decision addressed the outer boundaries of federalism via the third prong, ${ }^{190}$ and is important here because the VAWA, like the GFSZA, must be analyzed under the third prong. ${ }^{191}$ The Court held that the outer boundary of the third prong is represented by those statutes that regulate an "economic activity that might, through repetition elsewhere, substantially affect any sort of interstate commerce. ${ }^{192}$ In addition, a statute, such as a criminal statute, that "has nothing to do with . . . any sort of commercial enterprise," part of a larger regulation of economic activity, in which the regulatory scheme could be undercut unless the intrastate activity were regulated,"194 or (2) the statute possesses a "jurisdictional element, [that] ensure[s]" the specific act in question actually "affects interstate commerce."

Supporters of the VAWA argue that the regulated activity in the statute is discrimination and that the Court has always upheld discrimination statutes against commerce challenges, ${ }^{196}$ as it did in Heart

IBS See id. \$ 922(q)(2)(A).

${ }^{189}$ Doe v. Doe, 929 F. Supp. 608, 612 (D. Conn. 1996) (citing Loper, 514 U.S. at 558-59).

190 See Loper, 514 U.S. at 559 (stating that if the GFSZA is "to be sustained, it must be under the third category as a regulation of an activity that substantially affects interstate commerce").

${ }^{191}$ See Doe v. Doe, 929 F. Supp. at 612-15 (recognizing the application of the thirdprong analysis to the VAWA).

192 Loper, 514 U.S. at 567 (emphasis added).

199 Id. at 561.

194 Id. The Court reasoned:

Section 922(q) is not an essential part of a larger regulation of economic activity, in which the regulatory scheme could be undercut unless the intrastate activity were regulated. It cannot, therefore, be sustained under our cases upholding regulations of activities that arise out of or are connected with a commercial transaction, which viewed in the aggregate, substantially affects interstate commerce.

Id.

${ }^{195} I d$.

${ }^{196}$ See Maloney, supra note 186, at 1916-17 (arguing that the regulated activity is business, Congress's concern is the effect of discrimination on business, and the VAWA is constitutional based on Supreme Court precedent); Nourse, supra note 2, at 20 (" $[\mathrm{T}]$ he links to commerce... are precisely the same ones present in cases brought under sexual harassmert and race discrimination statutes."). 
of Atlanta Motel, Inc. v. United States ${ }^{197}$ and Katzenbach v. McClung. ${ }^{198}$ Focusing on the jurisdictional element, Victoria Nourse argues that Lopez prevents the Court from allowing individual effects on commerce to be combined "in cases where the statute provides no way of distinguishing between federal and state spheres of action." ${ }^{199}$ The VAWA supplies a distinguishing factor, however, because it does not preempt state regulation of the discrimination in the form of criminal prosecutions or state civil suits. ${ }^{200}$

Despite the strong arguments of the supporters, there is some language in Lopez that a reviewing court could seize upon to call the VAWA into question. For example, Chief Justice Rehnquist expressed his concern that prior court decisions were leading to a conversion of the commerce power into a "general police power." ${ }^{201}$ The Government argued that guns in schools threaten the learning environment which, in turn, will hamper the nation's future productivity. ${ }^{202}$ The Chief Justice countered that argument by noting that according to the Government's logic, "Congress could regulate any activity that it found was related to the productivity of individual citizens: family law (including marriage, divorce, and child custody). ${ }^{203}$ This concern, of course, echoes his federalism concerns about the earlier drafts of the VAWA. ${ }^{204}$

\section{B. Challenges to the VAWA in the Federal Courts}

To date, there have been six reported challenges to the constitutionality of the VAWA. ${ }^{205}$ The defendant(s) in each case filed a motion to dismiss and/or a motion for summary judgment, ${ }^{206}$ challeng-

197379 U.S. 241, 261 (1964) (upholding the Civil Rights Act of 1964 as applied to a private motel).

${ }^{198} 379$ U.S. 294, 305 (1964) (upholding the Civil Rights Act of 1964 as applied to a private restaurant).

${ }^{199}$ Nourse, supra note 2, at 21.

${ }^{200}$ See id. at 21-23 (noting that the VAWA contains such a distinguishing element).

${ }^{201}$ United States v. Lopez, 514 U.S. 549, 567 (1995); see also Maloney, supra note 186, at 1906-07 ("The Court's greatest fear, however, was authorizing Congress to pass any type of legislation under a plenary police power.").

${ }^{202}$ See Lopez, 514 U.S. at 563-64

${ }^{203}$ Id. at 564.

${ }^{204}$ See supra text accompanying notes $172-76$ (highlighting the federalism concerns).

${ }^{205}$ See supra notes 130-36 and accompanying text.

${ }^{206}$ See Doe v. Hartz, 134 F.3d 1339, 1341 (8th Cir. 1998) (motion to dismiss); Crisonino v. New York City Hous. Auth., 985 F. Supp. 385, 388 (S.D.N.Y. 1997) 
ing Congress's authority to enact the civil rights remedy under the Commerce Clause and the Fourteenth Amendment. ${ }^{207}$ Doe v. Doe, decided in June 1996, was the first case to consider the constitutionality of the VAWA. The district court in Doe v. Doe upheld the VAWA under the Commerce Clause, declining to reach the question of congressional authority under the Fourteenth Amendment. A month later in Brzonkala, the U.S. District Court for the Western District of Virginia, ${ }^{208}$ in an opinion by Judge Kiser, struck down the statute, holding that Congress lacked power under both the Commerce Clause and the Fourteenth Amendment. A three-judge panel of the Fourth Circuit Court of Appeals reversed Judge Kiser's opinion, and rehearing en banc is pending. ${ }^{209}$ In the meantime, the district courts in Seaton, Doe v. Hartz, Anisimov, and Crisonino upheld the VAWA under the Commerce Clause. ${ }^{210}$ Although the legal question in each case was the constitutionality of the VAWA under the two sources of congressional power, the Doe v. Doe, Brzonkala, Seaton, and Anisimov opinions each addressed the federalism concerns discussed above. The courts in Brzonkala and Seaton in particular appeared to be reasoning within the paradigm of privacy in their discussions of federalism. Finally, the Brzonkala opinion incorporated the DeShaney definition of state action.

(motion for summary judgment); Anisimov v. Lake, 982 F. Supp. 531, 532 (N.D. Ill. 1997) (motion to dismiss); Seaton v. Seaton, 971 F. Supp. 1188, 1190 (E.D. Tenn. 1997) (motion for summary judgment and motion to dismiss); Brzonkala v. Virginia Polytechnic \& State Univ., 935 F. Supp. 779, 783 (W.D. Va. 1996) (motion to dismiss), rev'd, 132 F.3d 949 (4th Cir. 1998), reh'g en banc granted and opinion vacated, WASH. POST, Feb. 8, 1998, at B3 (4th Cir. Feb. 5, 1998); Doe v. Doe, 929 F. Supp. 608, 610 (D. Conn. 1996) (motion to dismiss).

${ }^{207}$ See, e.g., 42 U.S.C. $\$ 13981$ (a) (1994) (asserting Congress's constitutional power to enact the VAWA); S. REP. NO. 102-197, at 52-53 (1991) (highlighting Congress's power to act under both the Commerce Clause and the 14th Amendment).

${ }^{203}$ In 1991, the same court held that the Virginia Military Institute's exclusion of women did not violate the Equal Protection Clause, a decision that the Supreme Court later overturned. See United States v. Virginia, 766 F. Supp. 1407 (W.D. Va. 1991), aff'd, 44 F.3d 1229 (4th Cir. 1995), rev'd, 116 S. Ct. 2264 (1996).

${ }^{200}$ The Fourth Circuit upheld the VAWA under the Commerce Clause. See Brzonkala v. Virginia Polytechnic Inst. \& State Univ., 132 F.3d 949, 973 (4th Cir. 1998) ("We hold that Congress had ... a rational basis in enacting VAWA."), reh'g en banc granted and opinion vacated, WASH. POST, Feb. 8, 1998, at B3 (4th Cir. Feb. 5, 1998). However, in February 1998, the Fourth Circuit granted rehearing en banc which occurred on March 3, 1998. The prior opinions, therefore, have no precedential value. See Telephone Interview with Clerk of Court, United States Court of Appeals for the Fourth Circuit (Mar. 31, 1998).

${ }^{210}$ See Crisonino, 985 F. Supp. at 395, 397; Anisimov, 982 F. Supp. at 540; Seaton, 971 F. Supp. at 1194; Doe v. Hartz, 970 F. Supp. 1375, 1434 (N.D. Iowa 1997), rev'd in part and vacated in part on other grounds, 134 F.3d 1339 (8th Cir. 1998). 


\section{Doe v. Doe Upheld the VAWA}

The Doe v. Doe action derived from a long-term abusive marriage. From 1978 to 1995, John Doe threw Jane Doe "to the floor, kick[ed] her, [threw] sharp and dangerous objects at her, threaten[ed] to kill her, and destroy[ed her] property." ${ }^{, 211} \mathrm{Mr}$. Doe also "forced her 'to be a "slave" and [to] perform all manual labor, including maintaining and laying out his clothes for his numerous dates with his many girlfriends and mistresses." ${ }^{212}$

In reaching its holding that the VAWA was within Congress's commerce power, ${ }^{213}$ the district court rejected numerous arguments by the defendant deriving from Lopez. The court held that Lopez did not overrule the two-part test articulated in Hodel v. Virginia Surface Mining $\mathcal{E}$ Reclamation Ass' $n$, ${ }^{214}$ for determining whether legislative action is within Congress's power under the Commerce Clause. ${ }^{215}$ First, Congress must have a rational basis for determining whether the regulated activity "sufficiently affects commerce." means chosen by Congress must be reasonably adapted to the ends. ${ }^{217}$

The district court distinguished the VAWA from the GFSZA in Lopex, pointing out that the VAWA was replete with legislative history concerning the effect of violence on commerce, ${ }^{218}$ whereas the statute

${ }^{211}$ Doe v. Doe, 929 F. Supp. 608, 610 (D. Conn. 1996).

${ }^{212} I d$.

${ }^{213}$ The Doe v. Doe case did not address the 14th Amendment issue.

214452 U.S. 264 (1981). The Hodel Court articulated the test of constitutionality under the Commerce Clause:

The task of a court that is asked to determine whether a particular exercise of congressional power is valid under the Commerce Clause is relatively narrow. The court must defer to a congressional finding that a regulated activity affects interstate commerce, if there is any rational basis for such a finding. This established, the only remaining question for judicial inquiry is whether "the means chosen by [Congress] must be reasonably adapted to the end permitted by the Constitution." The judicial task is at an end once the court determines that Congress acted rationally in adopting a particular regulatory scheme.

Id. at 276 (alteration in original) (citations omitted) (quoting Heart of Atlanta Motel, Inc. v. United States, 379 U.S. 241, 262 (1964)).

${ }^{215}$ Doe v. Doe, 929 F. Supp. at 613 (denying the defendant's argument that Lopez overruled Hodel's rationality test).

${ }^{216}$ Id. at 612 (citing Hodel, 452 U.S. at 276); see also United States v. Lopez, 514 U.S. 549 (1995) (same).

${ }^{217}$ See Hodel, 452 U.S. at 276.

${ }^{218}$ See Doe v. Doe, 929 F. Supp. at 615. 
in Lopez lacked such history. ${ }^{219}$ Because of the extensive legislative history, the court held that there was a rational basis to conclude that gender-based violence is a national problem affecting interstate commerce:

Certainly the repetitive nationwide impact of women withholding, withdrawing or limiting their participation in the workplace or marketplace in response to ... gender-based violence ... is of such a nature to be [a] substantial ... impact on interstate commerce....

... [T]his Court concludes that the statistical, medical, and economic data before the Congress adequately demonstrated the rational basis for Congress' findings that gender-based violence has a substantial effect on interstate commerce.

Next, the district court held that the statutory scheme adopted in the VAWA was "reasonably adapted to an end permitted by the Constitution." ${ }^{221}$ The court also rejected the defendant's federalism arguments that the VAWA “impermissibly 'federalizes' criminal, family law, and state tort law. ${ }^{222}$ Rather than encroaching upon state authority, the VAWA civil rights remedy serves as a federal supplement to existing state tort and criminal law. ${ }^{223}$

\section{Brzonkala Held the VAWA Unconstitutional}

In Brzonkala v. Virginia Polytechnic $\mathcal{E}^{2}$ State University, the U.S. District Court for the Western District of Virginia reached the opposite result, holding that the VAWA was unconstitutional under both the Commerce Clause and the Fourteenth Amendment. ${ }^{224}$ Although Judge Kiser's opinion has no precedential value, it illustrates the type of reasoning that the full Fourth Circuit or another reviewing court

219 See id. at 612 (noting the lack of legislative history in the GFSZA); see also Loper, 514 U.S. at 563 ("But to the extent that congressional findings would enable us to evaluate the legislative judgment that the activity in question substantially affected interstate commerce, ... they are lacking here.").

${ }^{220}$ Doe v. Doe, 929 F. Supp. at 614-15.

${ }^{221}$ Id. at 617.

${ }^{282} I d$. at 616.

${ }^{223}$ See id. at 616 ("The significance of this Act is its recognition of a federal civil right, with attendant remedies, which is distinct in remedy and purpose from state tort claims.... [T] here is no impermissible encroachment or federalization of states' traditional police powers."); see also S. REP. No. 103-138, at 51 (1993) (stating that the VAWA is not intended to create a general federal criminal law for assaults and rapes against women).

${ }^{224} 935$ F. Supp. 779, 782 (W.D. Va. 1996), rev'd, 132 F.3d 949 (4th Cir. 1997), reh'g en banc granted and opinion vacated, WASH. POST, Feb. 8, 1998, at B3 (4th Cir. Feb. 5, 1998). 
could adopt to strike down the VAWA. ${ }^{225}$ In addition, Judge Kiser's opinion still represents the only time a court has considered the VAWA's constitutionality under the Fourteenth Amendment.

The facts in the case are as follows. Two college football players, Morrison and Crawford, gang-raped Brzonkala, a classmate they had met thirty minutes earlier. After the rape, one of the players screamed at Brzonkala, "You better not have any fucking diseases." 226 Later, Morrison bragged publicly that he liked to get "girls drunk and fuck the shit out of them., ${ }^{227}$ At school disciplinary hearings, Morrison admitted having sexual contact with Brzonkala, and that she had told him "no" twice. ${ }^{28}$ Despite Morrison's admissions, Crawford denied that he had sexual contact with Brzonkala. ${ }^{229}$ Initially, the school suspended Morrison, but it later set aside the suspension and reduced the charge to "using abusive language." 230 The district court determined that the players' actions were sufficient to allow the case to go forward on the issue of whether there was "gender motivated animus." ${ }^{231}$ Nevertheless, the court dismissed the action on the ground that Congress lacked the authority to enact the VAWA under both the Fourteenth Amendment and the Commerce Clause. ${ }^{232}$

The court began its discussion of the Commerce Clause by explaining that the VAWA falls within the third category of activities ar-

${ }^{225}$ See supra note 209 (describing the procedural history of Brzonkala).

${ }_{226}$ Brzonkala, 935 F. Supp. at 782.

${ }^{227}$ Id. An unidentified male student-athlete also told Crawford that he should have "killed the bitch." Id.

${ }^{228}$ See id.

${ }^{229}$ See id.

${ }^{230}$ Id. at $781-82$.

${ }^{231}$ See id. at 784-85. The court found it significant that it was a stranger rape, a gang rape, and that the players did not use condoms. However, the court's analysis of the difference between stranger and date rape is highly problematic. Judge Kiser's opinion states that "date rape could involve a misunderstanding and is often less violent than stranger rape.... Date rape could also involve a situation where $a$ man's sexual passion provokes the rape by decreasing the man's control .... Finally, date rape could involve in part disrespect for the victim as a person, not as a woman..." Id. (emphasis added). These statements reflect the all-too-common misunderstandings that rape is about sexual passion, and that a rape perpetrated by a man who knows his victim is somehow less of a rape for the victim. In addition, it is unclear how one could hate a person stripped of her gender. The court went on to conclude, somewhat incomprehensibly, that although Morrison's statement that he likes to "fuck the shit" out of drunk women revealed a "history of taking pleasure from having intercourse ... without their sober consent," it did not mean that Morrison said that "he likes to rape women." Id. But see Anisimov v. Lake, 982 F. Supp. 531, 540-41 (N.D. Ill. 1997) (characterizing these findings as "dubious").

${ }^{232}$ See Brzonkala, 935 F. Supp. at 800-01. 
ticulated in Lopex, namely, "those activities having a substantial relation to interstate commerce. ${ }^{233}$ The court then proceeded to compare the GFSZA in Lopez to the VAWA civil rights remedy. It determined that "the regulated activity [in the VAWA] is the violent crime, whereas in Lopez the regulated activity was an act that could lead to a violent crime. ${ }^{234}$ He then determined that both the VAWA and the GFSZA focus on activities "too remote from interstate commerce," involve "intrastate activity" that is not "economic in nature," and lack jurisdictional elements limiting the statute to cases where the regulated activity affects interstate commerce. ${ }^{295}$ In reaching its decision, the court ignored the extensive congressional findings of the linkages between interstate commerce and violence against women in the VAWA legislative history, citing Lopez for the proposition that congressional findings are useful, but not decisive. ${ }^{236}$

The court concluded that allowing Congress to pass an act like the VAWA would give it constitutionally impermissible and unbounded power: "[I]f VAWA is a permissible use of the commerce power because of the regulated activity's effect on the national economy, which in turn affects interstate commerce, then it would be inconsistent to deny the commerce power's extension into family law, most criminal laws, and even insomnia., ${ }^{237}$

This language parallels Chief Justice Rehnquist's concern that the commerce power not become a stand-in for a "plenary police power." ${ }^{238}$ Like the Chief Justice's language in Lopez, the district court's Commerce Clause objections in Brzonkala share logical resonance with the early federalism objections to the VAWA discussed above. ${ }^{239}$ The court's conclusion that the VAWA is outside the scope of the commerce power may have been determined by its decision that the regulated activity is violent crime, ${ }^{240}$ not discrimination. This designation makes the parallel between the VAWA and the GFSZA appear more appropriate. The VAWA, however, is a civil rights remedy regulating the gender discrimination manifested in crimes of vio-

${ }^{293}$ See id. at 786 (identifying the three categories of permissible regulation).

234 Id. at 790; see id. at 791 ("VAWA regulates local criminal activity.").

${ }^{225} I d$.

${ }^{205}$ See id. at 789 ("The commerce power is based on a reasonable effect on interstate commerce, not on Congress's perceived effect on commerce.").

${ }^{257}$ Id. at 793 (emphasis added).

${ }^{239}$ United States v. Lopez, 514 U.S. 549, 566 (1995).

${ }^{299}$ See supra Part II.A.3.

${ }^{240}$ See supra text accompanying note 234. 
lence motivated by gender, not a criminal statute. ${ }^{241}$ The court's analogy would be more appropriate for a case challenging the new federal criminal offenses of interstate domestic violence, interstate stalking, and interstate violation of a protective order also created in the VAWA. ${ }^{242}$

The district court rejected the Fourteenth Amendment theory of congressional authority to enact the VAWA by appealing to the doctrine of state action. The court began by reading Kaztenbach $v$. Morgan $^{243}$ to require some degree of state action for an equal protection violation. ${ }^{244}$ It then announced that the standard for constitutionality would be "whether Congress's ends are legitimate" and "whether Congress's means are legitimate." 245 To determine whether the ends were legitimate, the court identified Congress's goals in enacting the VAWA- " $(1)$ to remedy private individuals' gender-based violence and (2) to remedy gender-based deficiencies in the states' criminal justice systems" ${ }^{246}$-and then searched for some element of state action.

The first goal failed because "[t]he state action at issue (the inadequacies in the state criminal systems) does not cause, or, in any significant manner, even contribute to, the deprivation caused by the individual criminal. ${ }^{247}$ The court rejected a Shelley $v$.

${ }^{241}$ The legislative history of the VAWA stresses the distinction between criminal prosecutions and civil rights remedies, namely that "[w] hile traditional criminal charges ... focus on the harm to the individual, a civil rights claim redresses an assault on a commonly shared ideal of equality." S. REP. NO. 102-197, at 49 (1991).

${ }^{242}$ See supra note 26 and accompanying text.

243384 U.S. 641 (1966) (upholding the Voting Rights Act of 1965).

${ }^{244}$ See Brzonkala v. Virginia Polytechnic \& State Univ., 935 F. Supp. 779, 794-95 (W.D. Va. 1996) ("Morgan does not permit Congress to act against purely private action incidentally giving rise to state action which causes a denial of equal protection."), rev'd, 132 F.3d 949 (4th Cir. 1997), reh'g en banc granted and opinion vacated, WASH. PosT, Feb. 8, 1998, at B3 (4th Cir. Feb. 5, 1998).

${ }^{245} \mathrm{Id}$. at 796-97.

${ }^{246} I d$. at 797. In Senate Report 138, Congress stated that its purpose was to "attack[] gender-motivated crimes that threaten women's equal protection of the laws" and to "provide[] a necessary remedy to fill the gaps and rectify the biases of existing State laws." S. REP. NO. 103-138, at 55 (1993).

${ }^{247}$ Brzonkala, 935 F. Supp. at 797. But see Amar \& Widawsky, supra note 9, at 1372 (arguing that so-called state inaction is really action because "when child abuse laws are not enforced, state custody law effectively grants parents absolute proprietary power to dominate and degrade their children"); $c f$. Schneider, supra note 147, at 978 (arguing that lack of state enforcement of domestic violence laws supports the batterer in his actions, leaving the victim to her own resources). 
Kraemer $^{248}$ interpretation of state action whereby the state's role in facilitating sex discrimination by inadequately enforcing its criminal statutes when women are the victims would constitute state action. The court distinguished Shelley stating that, in Shelley, a state actorthe court-enforced the private, discriminatory restrictive covenant while, in a hypothetical VAWA situation where the state declines to arrest a violent criminal, the state has not acted but has "'merely abstain [ed] from action." "249 Although the court did not cite DeShaney $v$. Winnebago County Department of Social Services, ${ }^{250}$ this language echoes the Supreme Court's language in that case. In DeShaney, a case involving abuse of a young child, the Court denied Joshua DeShaney's due process claim because the harm was caused by Joshua's father, not by the State of Wisconsin (despite state knowledge of and involvement with Joshua). ${ }^{251}$ Once again, the district court did not acknowledge that a private crime may also involve public discrimination.

The court found that the goal of eliminating state discrimination in the enforcement of criminal laws is a legitimate goal under Congress's Section 5 enforcement power. The court concluded, however, that the VAWA does not address this concern because the statute provides a remedy against individuals, not the state. ${ }^{252}$ In addition, the court found that the VAWA remedy is both overinclusive (providing a civil rights action for a woman whose state did not discriminate) and underinclusive (providing no remedy where the state discriminates, but the crime was not motivated by gender) ${ }^{253}$

${ }^{249} 334$ U.S. 1, $20-21$ (1947) (holding that a state court's enforcement of a racially discriminatory restrictive covenant constituted sufficient state action to implicate the 14th Amendment).

${ }^{249}$ Brzonkala, 935 F. Supp. at 799 (quoting Shelley, 334 U.S. at 19). This idea that state action only includes affirmative acts is increasingly being challenged by constitutional scholars. See, e.g., Amar \& Widawsky, supra note 9, at 1360-63 (questioning the formulation of state action in DeShaney); Minow, supra note 144, at 1668-76 (same); West, supra note 127, at 144 ("Whether the state's failure to protect constitutes an action or inaction ... is not determinative. What is determinative are the consequences of the state's conduct....").

2509 U.S. 189 (1989).

${ }^{251}$ See supra Part II.A.1 (analyzing the DeShaney decision).

252 See Brzonkala, 935 F. Supp. at 800 ("Instead of addressing the Fourteenth Amendment violation by the states' criminal justice system, VAWA authorizes a cause of action against an individual who did not contribute in any real sense to the unequal treatment in the states' criminal justice systems.").

${ }^{253}$ See id. 


\section{Subsequent Cases Upheld the VAWA Under the Commerce Clause}

The four district court cases decided after Brzonkala all upheld the VAWA under the Commerce Clause. Three of the courts first determined that the plaintiff adequately pled conduct that would be a crime of violence motivated by gender. In both Anisimov v. Lake ${ }^{254}$ and Crisonino v. New York City Housing Authority, ${ }^{255}$ plaintiffs sued their employers for violence that occurred at work. Anisimov alleged that her dentist/employer fondled her, grabbed her breasts, and assaulted and raped her in a remote location. ${ }^{256}$ Crisonino alleged that her supervisor called her a "dumb bitch"' and pushed her to the floor causing permanent injuries. ${ }^{257}$ In Seaton v. Seaton, Laurel Seaton sued her ex-husband for, among other claims, assault and sexual abuse that occurred during and after their marriage. ${ }^{258}$ In Doe v. Hartz, Doe alleged that "Father Hartz "came up behind her, grabbed her with both of his hands and pulled her back into his body, held her tightly and kissed her neck'"259 when she arrived at church to sing for Mass.

254982 F. Supp. 531 (N.D. Ill. 1997).

255985 F. Supp. 385 (S.D.N.Y. 1997).

${ }^{256}$ See Anisimov, 982 F. Supp. at 532. The court held that the rape constituted a crime of violence motivated by gender. See id. at 541 ("The Court finds that Anisimov's allegations.... are sufficient to... state a claim under the VAWA's Civil Rights Remedy.").

${ }^{257}$ Crisonino, 985 F. Supp. at 388 . The Court found that the alleged conduct constituted a crime of violence motivated by gender. The elements of a crime of violence motivated by gender were met because the conduct alleged could be a felony and a jury could reasonably conclude that calling the plaintiff "dumb bitch" and then throwing her to the floor was "due, at least in part, to an animus based on her gender." Id. at 391 .

${ }^{258} 971$ F. Supp. 1188,1189 (E.D. Tenn. 1997). The pendant state law tort claims, except for claims related to assaults within one year, were dismissed because of the one-year statute of limitations in Tennessee. See id. at 1195.

${ }^{259}$ Doe v. Hartz, 970 F. Supp. 1375, 1381 (N.D. Iowa 1997), rev'd in part and vacated in part on other grounds, 134 F.3d 1339 (8th Cir. 1998). The district court determined that Doe "has adequately pleaded, although just barely, each of the essential elements of a [VAWA] claim." Id. at 1434. The court held that the "predicate offense," the Iowa crime of sexual exploitation by a counselor or a therapist, see IOWA CODE ANN. $\S 709.15$ (West 1993), was a crime of violence motivated by gender. See Doe v. Hartz, 970 F. Supp. at 1397-404. The Court of Appeals for the Eighth Circuit reversed, holding that Hartz's conduct as pled by Doe was not a crime of violence motivated by gender because it would only constitute an aggravated misdemeanor under Iowa law. See Doe v. Hartz, 134 F.3d 1339, 1342-43 (8th Cir. 1998). In addition, the court held that Doe "has not stated a claim under the VAWA because she has failed to plead a violation of the Iowa statute, the predicate offense upon which she relies." Id. 
To determine if Congress had the power to enact the VAWA pursuant to its Commerce Clause powers, each of the district courts followed Doe v. Doe in using the two-part Hodel test. ${ }^{260}$ The Anisimov court articulated the test in a manner similar to the other three courts when it said: "The question before this Court is whether a rational basis exists for concluding that gender-motivated violence affects interstate commerce. And if it does, whether the VAWA is a reasonably adapted means to the intended goal of Congress. ${ }^{\text {.261 }}$

In determining that there was a rational basis, each court gave significant weight to the extensive congressional findings linking violence against women to interstate commerce. ${ }^{262}$ All four courts remarked on the fact that there were four years of congressional hearings and were impressed by the amount and seriousness of Congress's findings. ${ }^{263}$ The Seaton court, for example, found that Congress had a rational basis to conclude that violence against women substantially affects interstate commerce when "one-half of the nation's population is potentially limited in employment, traveling, and participation in commercial spending due to the threat of violence. ${ }^{264}$ The court continued:

${ }^{260}$ See Crisomino, 985 F. Supp. at 395-96 (adopting the Hodel test); Anisimov, 982 F. Supp. at 538 (citing Hodel v. Virginia Surface Mining \& Reclamation Ass'n, 452 U.S. 264, 276 (1981)); Seaton, 971 F. Supp. at 1192 (quoting Hodel 452 U.S. at 276); Doe v. Hartz, 970 F. Supp. at 1415 (citing United States v. Lopez, 514 U.S. 549, 557 (1995), and Hodel, 452 U.S. at 276); see also Brzonkala v. Virginia Polytechnic Inst. \& State Univ., 132 F.3d 949, 968 n.11 (4th Cir. 1997) (citing decisions from the 10 circuits employing the rational basis test post-Lopez), reh'g en banc granted and opinion vacated, WASH. POST, Feb. 8, 1998, at B3 (4th Cir. Feb. 5, 1998).

201 Anisimov, 982 F. Supp. at 538.

${ }^{202}$ The courts differed slightly in the amount of weight to be given congressional findings, but all agreed that congressional findings were still relevant after Lopez. See Crisonino, 985 F. Supp. at 395 (citing Loper, 514 U.S. at 562, for the proposition that courts should "consider" legislative findings in their "independent evaluation' of constitutionality"); Anisimov, 982 F. Supp. at 539 (stating that congressional findings receive deference); Doe v. Hartz, $970 \mathrm{~F}$. Supp. at 1422 ("[I]n light of these findings, giving them the deference they are properly due in a Commerce Clause analysis, this court finds that there was undeniably a rational basis for Congress's conclusions that gender-motivated violence has a substantial effect on interstate commerce."); see also Brzonkala, 132 F.3d at 968 (citing cases concerning the high level of deference given to congressional findings, post-Lopez).

2is See Crisonino, 985 F. Supp. at 395 (referring to "four years of hearing and study" and "voluminous legislative findings," and quoting the "more compelling" findings); Anisimov, 982 F. Supp. at 537 (characterizing the congressional findings as "startling"); Seaton, 971 F. Supp. at 1192 (stating that Congress cited a "plethora of shocking statistics"); Doe v. Hartz, $970 \mathrm{~F}$. Supp. at 1421 (characterizing the findings as "staggering"); see also Brzonkala, 132 F.3d at 964 (referring to a "mountain of evidence").

${ }^{264}$ Seaton, 971 F. Supp. at 1194. 
[I] $t$ is unlikely that Congress would spend four years determining the effects of gender-based violence on interstate commerce for the sole purpose of overcoming the rationality test.... Therefore, it is apparent that ... the legislative findings suffice under the rational basis test to place VAWA within the rubric of the Commerce Clause. ${ }^{265}$

The Anisimov court used even stronger language, stating that "this court believes that to set aside four years of extensive and wellreasoned congressional findings demonstrating the substantial effect of gender-motivated violence on interstate commerce would be to usurp a constitutional role that the Court was not allotted. ${ }^{266}$

The courts then turned to the question of whether the VAWA remedy was a "reasonably adapted means to the intended goal of Congress"- to address violence against women. ${ }^{267}$ The courts found that the remedy was reasonably adapted, particularly in light of the long tradition of civil rights legislation under the Commerce Clause addressing private discrimination. ${ }^{268}$ The Crisonino court, for example, wrote that the VAWA "fits squarely within the tradition of federal civil rights legislation. ${ }^{269}$

Although the structure of the four decisions is remarkably similar, the tone set by each court is very different. In Seaton, in particular, Judge Jarvis "reluctantly" upheld the VAWA. ${ }^{270}$ The court's reluctance stemmed from federalism concerns about the civil rights remedy, as discussed in Part II.A.3: "[T] he court must note its extreme discomfort with the sweeping nature of VAWA. ... The Framers of the Constitution did not intend for the federal courts to play host to domestic

${ }^{265}$ Id.; see also Brzonkala, 132 F.3d at 973 ('In light of Congress's findings well supported by testimony and data, we hold that Congress had ... a rational basis in enacting VAWA.").

${ }^{266}$ Anisimov, 982 F. Supp. at 539.

267 Seaton, 971 F. Supp. at 1194.

${ }^{268}$ See Crisonino, 985 F. Supp. at 397 (characterizing the VAWA as a "reasonable means to a legitimate end"); Anisimov, 982 F. Supp. at 540 (same); Seaton, 971 F. Supp. at 1194 (same); Doe v. Hartz, 970 F. Supp. at 1434 (“[T] he means Congress adopted in the civil remedies provision of the VAWA to combat gender-motivated violence were reasonably adapted to that goal.").

${ }^{269}$ Crisonino, 985 F. Supp. at 397; see also Doe v. Hartz, 970 F. Supp. at 1434 (stating that the VAWA "mirror[s] other statutory provisions for private enforcement of civil rights").

${ }^{270}$ Seaton, 971 F. Supp. at 1193 ("This court is quite reluctantly inclined to agree with the Doe court and finds that Congress had a rational basis for determining that violence against women sufficiently affects interstate commerce."); see also id. at 1194 95 (stating that although the court is "convinced" Congress "could have drafted a better law" and "disagree[s] with the inclusiveness of VAWA, the Act itself is not an unreasonable means to the ends intended by Congress"). 
disputes and invade the well-established authority of the sovereign states." $^{271}$

The Anisimov court disagreed, stating that the VAWA is not an invasion of state sovereignty because it is a civil rights remedy that does not "duplicate or usurp the authority of the States." 272 Nevertheless, that court also expressed some uncertainties concerning the scope of the commerce power because of the enduring "unanswered" questions after Lopez ${ }^{273}$ Accordingly, the Anisimov court certified the question of VAWA's constitutionality for an interlocutory appeal to the Seventh Circuit, stating that the issue of constitutionality "involves a controlling question of law as to which there is a substantial ground for a difference of opinion. ${ }^{274}$

\section{Privacy, Federalism, State Action, and the Thirteenth Amendment}

The consensus among the courts that have considered the constitutionality of the VAWA under the Commerce Clause seems to be that the VAWA civil rights remedy is constitutional. ${ }^{275}$ Nevertheless, the Anisimov court's certification of the question regarding the constitutionality of the VAWA under the Commerce Clause for interlocutory appeal indicates that the VAWA's constitutionality under the Commerce Clause remains an open question. In addition, only the Brzonkala district court opinion has addressed whether Congress had

271 Id. at $1190-91$.

${ }^{272}$ Anisimov, 982 F. Supp. at 540 ("The Supreme Court has historically recognized that with respect to civil rights legislation: "The power of Congress ... is broad and sweeping; where it keeps within its sphere and violates no express constitutional limitation it has been the rule of this Court ... not to interfere." (quoting Katzenbach v. McClung, 379 U.S. 294, 305 (1964))); see also Brzonkala v. Virginia Polytechnic Inst. \& State Univ., 132 F.3d 949, 971 (4th Cir. 1997) ("VAWA acts to supplement, rather than supplant, state criminal, civil, and family law controlling gender violence."), reh'g en banc granted and opinion vacated, WASH. POST, Feb. 8, 1998, at B3 (4th Cir. Feb. 5, 1998).

${ }^{273}$ See Anisimov, 982 F. Supp. at 535 (listing three outstanding issues and proclaiming itself "not alone in ... uncertainty concerning how the Supreme Court will approach these issues when it considers future challenges to congressional authority under the Commerce Clause").

${ }^{274}$ Id. at 541 (citing the 28 U.S.C. $\$ 1292$ (b) standards for an interlocutory appeal); see also Doe v. Hartz, $970 \mathrm{~F}$. Supp. at 1435 (certifying a question for interlocutory appeal and citing the split between the then two district court opinions as the basis for concluding there is a "substantial ground for difference of opinion").

${ }^{275}$ See Mattison v. Click Corp. of Am., Civ. A. No. 97-CV-2736, 1998 WL 32597, at *6 (E.D. Pa. Jan. 27, 1998) (mem.) (citing decisions rejecting "constitutional challenges to the VAWA" and concluding that "[ $t$ ] he reasoning [in the opinions] is compelling and clearly supports the conclusion that the VAWA passes constitutional muster ${ }^{m}$ ). 
the power to enact the VAWA pursuant to Section 5 of the Fourteenth Amendment. Commentators predict that the Supreme Court will hear a VAWA case when the opportunity arises. ${ }^{276}$

When that case is argued, a Thirteenth Amendment theory may provide additional constitutional authority for the VAWA civil rights remedy by rebutting arguments against the statute based on (1) the historically pedigreed doctrines of privacy and the federal domesticrelations exception; (2) the doctrine that state action encompasses only affirmative state action; or (3) an interpretation of Lopez that excludes the remedy from the realm of legitimate congressional authority. The Thirteenth Amendment cuts through distinctions based on the public-private dichotomy because the Thirteenth Amendment has always reached into the private realm. ${ }^{277}$ The Thirteenth Amendment deflates federalism objections because, by its very enactment, it superseded federalism. ${ }^{278}$ The Thirteenth Amendment erases any distinction between positive and negative state action because it has never required state action. ${ }^{279}$ Additionally, a Thirteenth Amendment theory nullifies Lopez objections because the VAWA need not rely on the commerce power. If the right to be free from gender-motivated violence can be found within the Thirteenth Amendment, then privacy, state action, and federalism objections must yield to the new civil rights remedy. In Part III, the relationship between the Thirteenth Amendment and violence against women will be explored to show how the VAWA is at the center of Thirteenth Amendment concerns. ${ }^{280}$

${ }^{276}$ See, e.g., Duncan Mansfield, Gender-Motivated Violence Law Survives Fed Court Test in Tenn., DAILY REC., July 11, 1997, at 24 (stating that appeals of the VAWA are expected to reach the Supreme Court); Tony Mauro, Court Cools After Hot Term: Following a Rash of Groundbreaking Cases, the Court Sees a Quieter Time, LEGAL. TIMES, Oct. 6, 1997, at S32 (predicting that the Court might hear a VAWA case in the near future).

${ }^{277}$ See The Civil Rights Cases, 109 U.S. 3, 23 (1883) ("Under the thirteenth amendment, the legislation ... may be direct and primary, operating upon the acts of individuals ...."); see also Griffin v. Breckenridge, 403 U.S. 88, 105 (1971) ("[S]urely there has never been any doubt of the power of Congress to impose liability on private persons under [the 13th Amendment] ....").

${ }^{278}$ See Jacobus tenBroek, Thirteenth Amendment to the Constitution of the United States, 39 CAL. L. REV. 171, 174 (1951) (characterizing the 13th Amendment as a "revolution in federalism" and stating that opponents of the amendment believed it to be an "invasion of the rights of the states and a corresponding unwarrantable extension of the power of the central government").

${ }^{279}$ See The Civil Rights Cases, 109 U.S. at 23 ("[T]he Thirteenth Amendment ... may be direct and primary, operating upon the acts of individuals, whether sanctioned by State legislation or not ....").

${ }^{280}$ See Amar \& Widawsky, supra note 9, at 1373-74 (arguing that the 13th Amendment should supersede the traditional parent-child relationship and reach into the 


\section{REJECTING SETTLED CONSTITUTIONAL INTERPRETATION: A PROPOSED THIRTEENTH AMENDMENT THEORY FOR CONGRESSIONAL POWER TO ENACT THE VAWA}

In 1878, Elizabeth Cady Stanton said the following about constitutional interpretation:

"A century of discussion has not yet made the constitution understood .... It has no settled interpretation. Being a series of compromises, it can be expounded in favor of many directly opposite principles.... [T] he numerous demands by the people for national protection in many rights not specified by the constitution, prove that the people have outgrown the compact that satisfied the fathers." ${ }^{281}$

Although Stanton addressed the Constitution's failure to encompass women's suffrage, ${ }^{282}$ her words are an appropriate introduction to a discussion of whether the Thirteenth Amendment provides constitutional authority for the VAWA civil rights remedy. This Comment directly conflicts with the settled interpretation of the Thirteenth Amendment in formulating a constitutional basis for the VAWA. It follows a newer strain of Thirteenth Amendment theory that aims to return the Amendment to its full power-to a time before limiting glosses were added by post-Reconstruction courts. ${ }^{283}$

family where there is severe child abuse because, if the 13th Amendment never comes between parent and child, then many slave masters would have been able to circumvent the amendment by claiming those slaves who were also their biological children).

${ }^{281}$ Ellen Carol DuBois, Outgrowing the Compact of the Fathers: Equal Rights, Woman Suffrage, and the United States Constitution 1820-1878, in A LESS THAN PERFECT UNION: ALTERNATIVE PERSPECTIVES ON THE U.S. CONSTITUTION 104, 131 (Jules Lobel ed., 1988) [hereinafter A LESS THAN PERFECT UNION] (emphasis added) (quoting 3 HISTORY OF WOMAN SUFFRAGE 87, 88 (Elizabeth Cady Stanton et al. eds., Rochester, John Dick 1881)).

${ }^{282}$ See id. passim.

${ }^{233}$ See Amar, Remember the Thirteenth, supra note 9 (describing the variety of issues to which the 13th Amendment can be applied, including child abuse and hate speech); Amar, Women and the Constitution, supra note 9, at 467 ("Women ... were in large part the agents and the subjects of the Thirteenth Amendment."); Amar \& Widawsky, supra note 9, at 1360 (arguing that the 13th Amendment "provides the best constitutional vehicle" to address child abuse); Douglas L. Colbert, Liberating the Thirteenth Amendment, 30 HARV. C.R.-C.L. L. REV. 1, 5 (1995) (explaining the 13th Amendment's "vast untapped potential as a teaching and litigation tool"); Andrew Koppelman, Forced Labor: A Thirteenth Amendment Defense of Abortion, 84 Nw. U. L. REV. 480 (1990) (substituting the 13th Amendment as the constitutional authority for Roe v. Wade); McConnell, supra note 9 (arguing that severe battering is 13th Amendment involuntary servitude); tenBroek, supra note 278 (rejecting a limited scope for the 13th Amendment); Jennifer L. Conn, Note, Sexual Harassment: A Thirteenth Amendment Response, 28 ColuM. J.L. \& SoC. PROBS. 519 (1995) (applying the 13th Amendment to sexual harassment); Neal Kumar Katyal, Note, Men Who Own Women: A Thirteenth 


\section{A. Settled Interpretation of the Thirteenth Amendment}

The settled interpretation of the Thirteenth Amendment is that it applies only to situations of forced labor analogous to chattel slavery ${ }^{284}$ and that its implementing statutes reach only discrimination based on race. $^{285}$ Section 1 of the Thirteenth Amendment abolished slavery and involuntary servitude forever, commanding that "[n]either slavery nor involuntary servitude... shall exist."286 Section 2 granted Congress the authority to legislate to enforce the command of Section $1 .{ }^{287}$ In the Civil Rights Cases, the Court explained that enforcement meant the power to regulate the "badges and incidents" of slavery. ${ }^{288}$ The Court's definition of badges and incidents derived, in turn, from the Civil Rights Act of $1866,{ }^{289}$ which was Congress's first exercise of the Section 2 power and an attempt to clarify the nature of the rights of citizenship housed in the Amendment. Those rights of citizenship include the fundamental rights which are the essence of civil freedom, namely, "the [same] right to make and enforce contracts, to sue, be parties, and give evidence, to inherit, purchase, lease, sell, hold, and convey... property... as is enjoyed by white citizens." ${ }^{290}$ Therefore, the Thirteenth Amendment abolished slavery and involuntary servitude and granted Congress authority to legislate against any deprivation of the rights enumerated in the Civil Rights

Amendment Critique of Forced Prostitution, 103 YALE L.J. 791, 793 (1993) (arguing that the 13th Amendment "reaches ... forced prostitution").

${ }^{284}$ See, e.g., Colbert, supra note 283, at 28 ("For most of the Amendment's first century, scholars did not dispute the Supreme Court's doctrine and dogmatically advanced two themes: first, the Amendment's prohibitions applied only to situations involving enforced compulsory service; and second, the Amendment did not contain affirmative rights protections.").

${ }^{285}$ For example, 42 U.S.C. $\$ 1981$ has been interpreted to cover racial, but not gender, discrimination. See Bobo v. ITT, Continental Baking Co., 662 F.2d 340, 344 (5th Cir. Nov. 1981).

${ }_{285}$ U.S. CoNST. amend. XIII, § 1; see The Civil Rights Cases, 109 U.S. 3, 20 (1883) (noting that the 13th Amendment "is not a mere prohibition of State laws establishing or upholding slavery, but an absolute declaration that slavery ... shall not exist in any part of the United States" (emphasis added)); see also Jones v. Alfred H. Mayer Co., 392 U.S. 409,438 (1968) (reaffirming this principle).

${ }_{287}$ See U.S. CONST. amend. XIII, \$ 2.

${ }^{288}$ See The Civil Rights Cases, 109 U.S. at 20 (stating that Congress has the power to "pass all laws necessary and proper for abolishing all badges and incidents of slavery in the United States").

${ }^{289}$ Civil Rights Act of 1866, ch: 31, $\S 1,14$ Stat. 27 (codified as amended at 42 U.S.C. $\S 1981$ (1994)).

200 Id. 
Acts. This traditional view is strengthened by the now canonical story that

the Thirteenth Amendment [was] only the first step in a comprehensive three-step plan designed, first, through the Thirteenth Amendment, to abolish chattel slavery; second, through the Fourteenth Amendment, to restore the freed Negro to a condition of civil equality; and third, through the Fifteenth Amendment, to safeguard him in his political rights....2.

Women fit into this narrative, if at all, as freed slaves, or as the beneficiaries of a lesser form of equal protection. ${ }^{292}$ Married women were subject to the loss of citizenship rights inherent in common-law marriage until the passage of the Married Women's Property Acts. ${ }^{293}$ Full political rights for women, the story continues, would not come until 1920 with the adoption of the Nineteenth Amendment. ${ }^{294}$ To this day, the promise of the Thirteenth Amendment for women is split down race lines. All women may claim the Amendment's protections against states of servitude recognized in the implementing antipeonage and involuntary servitude statutes. ${ }^{205}$ Black women may invoke the civil rights statutes based on the Thirteenth Amendment for claims of racial discrimination. ${ }^{296}$ Thus, a black woman must choose an approach that often obscures the complex interplay of racial and sexual discrimination and the historical fact that slavery was different for men and women. ${ }^{297}$

${ }^{201}$ tenBroek, supra note 278 , at 173 . This view was judicially recognized at least as early as the Slaughter-House Cases. See Slaughter-House Cases, 83 U.S. (16 Wall.) 36, 7072 (1872).

${ }^{252}$ See supra notes 159-61 and accompanying text.

${ }^{203}$ The Married Women's Property Acts guaranteed women the "right to sue, to be sued, to contract, and to own property." McConnell, supra note 9, at 249.

${ }^{29}$ See U.S. CONST. amend XIX; see also Amar, Women and the Constitution, supra note 9, at 471 (arguing that the 19th Amendment restored symmetry to the Constitution by assuring the same rights for women and African-Americans).

${ }_{201}$ See 42 U.S.C. $\$ 1994$ (1994) (peonage); 18 id. \$§ 1581-1588 (peonage and involuntary servitude); see also Pierce v. United States, 146 F.2d 84 (5th Cir. 1944) (convicting Pierce of holding women in a state of peonage by forcing them to commit acts of prostitution to repay debts incurred when Pierce paid fines for their release from prison).

${ }_{296}$ See, e.g., Patterson v. McLean Credit Union, 491 U.S. 164, 185 (1989) (finding that Patterson, a black woman, could use 42 U.S.C. $\$ 1981$, prohibiting racial discrimination in the formation of contracts, as a basis for her claim of racially discriminatory failure to promote).

${ }^{297}$ Kimberle Crenshaw argues that under current Title VII law, black women are forced to fit their claims into either a race or a sex discrimination model, an approach 


\section{B. A Proposed Thirteenth Amendment Theory Supporting the Civil Rights Remedy}

This Comment presents two theories that justify Congress's authority to enact the VAWA under Section 2 of the Thirteenth Amendment.

First, severe domestic violence, ${ }^{298}$ child abuse, and child sexual abuse $^{299}$ are involuntary servitude. Section 2 grants Congress the authority to legislate against involuntary servitude in whatever form it may take. ${ }^{300}$ Accordingly, Congress possesses constitutional authority to enact those parts of the VAWA civil rights remedy that provide relief for women and girls in severely abusive relationships. ${ }^{301}$ Other forms of modern violence against women, such as one-time rapes and assaults, may also be reachable as incidents of the modern involuntary servitude of severe battering.

Second, modern violence against women is a badge and incident of nineteenth-century slavery and of the nineteenth-century involuntary servitude of coverture. Although slavery, as experienced by black women, and coverture, as experienced by white women, were different in degree, each involved reduced citizenship rights and elements of violence. Today, violence against women still prevents women

which obscures the effect of combined discrimination and is best suited for those within a class that are either "race" or "sex privileged":

[T] he paradigm of sex discrimination tends to be based on the experiences of white women; the model of race discrimination tends to be based on the experiences of the most privileged Blacks. Notions of what constitutes race and sex discrimination are, as a result, narrowly tailored to embrace only a small set of circumstances, none of which include discrimination against Black women.

Kimberle Crenshaw, Demarginalizing the Intersection of Race and Sex: A Black Feminist Critique of Antidiscrimination Doctrine, Feminist Theory and Antiracist Politics, 1989 U. CHI. LEGALF. 139, 151.

${ }^{298}$ Joyce McConnell argues that severe domestic violence is involuntary servitude. See McConnell, supra note 9, at 209 ("[T]he key distinction between the battered women's cases and the judicially recognized cases of involuntary servitude is the intimate origin of their relationships and not the degree or nature of the coercion ....").

299 Akhil Amar and Daniel Widawsky argue that child abuse is slavery. See Amar \& Widawsky, supra note 9, at 1385 ("[T] he State ... can be understood as enforcing this servitude by rendering [the child] to his father, just as slaves were rendered to their masters.").

${ }^{300}$ See U.S. CONST. amend. XIII, $\$ 2$ ("Congress shall have power to enforce this article by appropriate legislation.").

sol This argument is an extension of McConnell's thesis. See McConnell, supra note 9 , at 251 (" $[\mathrm{A}]$ civil cause of action and remedy could be implied from the language of the [13th A]mendment itself or from the federal involuntary servitude statute...."). 
from exercising their full citizenship rights. Therefore, just as Congress can enact legislation that addresses other badges and incidents of nineteenth-century slavery, ${ }^{302}$ it has the power to enact the VAWA.

\section{A Working Definition of Slavery}

The Thirteenth Amendment is absolute in its command that " $[n]$ either slavery nor involuntary servitude ... shall exist within the United States." ${ }^{303}$ The amendment forbids whatever is or was understood to be slavery. Slavery has been described as a system of "dominance and subservience" by Akhil Amar and Daniel Widawsky: "The central concern of the Amendment is not labor, not adulthood, not blackness, not state action, not biology, but slavery-a system of dominance and subservience, often on a personal scale, and the reduction of human beings to the status of things." ${ }^{\text {304 }}$ Amar and Widawsky further point out that many antebellum legal thinkers shared this view. For example, in 1829, Judge Ruffin of the North Carolina Supreme Court wrote: "Such obedience [of a slave to a master] is the consequence only of uncontrolled authority over the body.... The power of the master must be absolute, to render the submission of the slave perfect." ${ }^{\text {305 }}$

Slavery circumscribed the public/marketplace and private/familial spheres-especially for women. ${ }^{306}$ For women, slavery involved not only work in the field and housework in the master's house, but also rape, physical assault, reproductive services, and the torture of watching their children be harmed or sold. ${ }^{307}$ Describing the experience of slave women, Deborah White writes:

$\$^{\$ 22}$ See supra Part III.A.

${ }^{\$ s 9}$ U.S. CONST. amend. XIII, § 1; see also Amar \& Widawsky, supra note 9, at 1359 ("[The 13th Amendment's] framers' disgust with 'the peculiar institution' led them to announce a more universal, transcendent norm: slavery, of all forms and in all places, shall not exist .... The Amendment embraced not only those slaves with some African ancestry, but all persons, whatever their race or national origin.").

9.4 Amar \& Widawsky, supra note 9, at 1384.

sos Id. at 1370.

sso See Deborah GRAY WhITE, AR'N'T I a WOMAN: FEMALE SLAVES IN THE PLANTATION SOUTH 69 (1985) ("Male slavery centered mostly around the work that black men did for whites. Female slavery had much to do with work, but much of it was concerned with bearing, nourishing, and rearing children ...."); McConnell, supra note 9, at 217 ("To focus only on the economic aspect of slavery as a system of production in the public sphere is to remove slavery from its hellish private context.").

${ }^{507}$ For a comprehensive treatment of the work performed by slave women, see WHITE, supra note 306. See also McConnell, supra note 9, at 219-20 (“[A]long with forced economic production and domestic tasks, with their obvious counterparts in 
Once slaveholders realized that the reproductive function of the female slave could yield a profit, the manipulation of procreative sexual relations became an integral part of the sexual exploitation of female slaves. Few of the calculations made by masters and overseers failed to take a slave woman's childbearing capacity into account. ${ }^{\text {308 }}$

If Congress outlawed all aspects of chattel slavery, then Congress outlawed its private and familial aspects as well. ${ }^{309}$ Moreover, if slavery for women in the nineteenth century involved sexualized violence and beatings, then those parts of slavery were also abolished. Thus, any parallel relationship in the twentieth century involving sexualized violence and assault directly implicates the Thirteenth Amendment. ${ }^{310}$ It should not matter to a Thirteenth Amendment analysis that the incidents of slavery were differentiated based on sex and that animus towards a slave took a different form based on his or her sex. Therefore, the Thirteenth Amendment includes slavery's gender-specific incidents and is not limited to marketplace or employer-employee relationships. ${ }^{311}$

the free wage-labor system, came other personal services such as sex and reproduction.").

Sas WHITE, supra note 306, at 68.

${ }^{509}$ See Slaughter-House Cases, 83 U.S. (16 Wall.) 36, 72 (1872) ("Undoubtedly while negro slavery alone was in the mind of the Congress which proposed the thirteenth article, it forbids any other kind of slavery, now or hereafter."); Amar \& Widawsky, supra note 9, at 1368 ("To end slavery was thus to radically restructure this 'private' sphere, and to reorder not simply the political and economic system but the social fabric as well.").

${ }^{310}$ See McConnell, supra note 9, at 220 ("[I]n adopting the Thirteenth Amendment, Congress not only forbade the legal ownership of human chattel (slavery) but prohibited anyone from treating another as if such ownership existed (involuntary servitude).").

${ }^{311}$ See Amar \& Widawsky, supra note 9, at 1369 ("[A]lthough forced labor for economic gain was one characteristic of slavery as practiced in the antebellum South, forced labor itself does not exhaust the meaning of slavery."); McConnell, supra note 9, at 211-15 (arguing that the original conception of the Amendment included more than labor relationships). 


\section{Original Intent of the Thirteenth Amendment ${ }^{312}$}

The common wisdom-that the Thirteenth Amendment holds no special promise for women's liberation-was not a settled interpretation in the 1860s. At the time of the congressional debates concerning the Amendment, opponents, abolitionists, and women's rights activists all recognized the Amendment's potential to create sweeping new rights for both freed black women and married white women. ${ }^{313}$

During the Thirteenth Amendment debates, opponents of the Amendment conjured up the specter of a reordering of the relationship between husband and wife. ${ }^{314}$ The master/slave and husband/wife relationships, after all, were among the many classic legal relationships with shared justifications. Representative White, for example, protested that

[t]he parent has the right to the service of his child; he has a property in the service of that child. A husband has a right of property in the service of his wife; he has the right to the management of his household affairs.... All these rights rest upon the same basis as a man's right of property in the service of slaves. ${ }^{315}$

Opponents to the change in federalism wrought by the Amendment also equated the change with a breakdown in all of the classic common-law relationships. For example, Representative Cox, who claimed to object to the amendment because it would alter the balance of federalism, fulminated:

The effort is now to make... abolition a function of the national Government.... Should we amend the Constitution so as to change the relation of parent and child, guardian and ward, husband and wife, the laws of inheritance, the laws of legitimacy? Where will it end, when once be-

${ }^{312}$ Critical scholars have attacked the validity of using original intent to interpret the Constitution. Randall Kennedy writes:

[T] $\mathrm{T}$ e endeavor to confine choice by reference to the intentions of white men situated in the eighteenth or nineteenth century should be rejected as aspiration because, if followed, it would quite likely portend the nullification of legal achievements that support the rights of racial minorities and others whose interests in previous centuries generally had a lower level of priority than obtains today.

Randall L. Kennedy, Race and the Fourteenth Amendment: The Power of Interpretational Choice, in A LESS THAN PERFECT UNION, supra note 281, at 273, 275.

${ }^{313}$ See DuBois, supra note 281 , at 113 (discussing the women's rights activists' views that the 13th Amendment opened doors to new freedoms for women).

${ }^{314}$ See McConnell, supra note 9, at 215-16 ("Some Congressmen expressed concern that the Thirteenth Amendment had the potential to reach into the private sphere of the home and to alter the traditional relationship between husband and wife.").

${ }^{315}$ CONG. GLOBE, 38th Cong., 2d Sess. 215 (1865) (statement of Rep. White). 
gun? Is it, then, a question of slavery, or is it a question of home freedom in home affairs; a State question in State affairs; a police question, concerning municipal and not Federal institutions? ${ }^{316}$

The view that married women's rights could be affected by the Thirteenth Amendment was invoked again one year later during the debates surrounding the passage of the Civil Rights Act of 1866, which clarified the scope of the Amendment. For example, Senator Cowan charged that the language of the Civil Rights Act of 1866 would grant women the right to make and enforce contracts, which would clearly be unconstitutional because the Thirteenth Amendment did no more than free those enslaved in the 1860s:

What is the fair construction of that amendment of the Constitution abolishing slavery?... What was the involuntary servitude mentioned there? ... Was it the right the husband had to the services of his wife? Nobody can pretend that [was] within the purview of that amendment; nobody believes it. It was mentioned as a matter of ridicule, in some places... that it did actually entitle the wife to be paid for her own services, that they should not go to the husband .... The true meaning and intent of that amendment was simply to abolish negro slavery.

Although opponents of Reconstruction may have only intended to derail the Civil Rights Act of 1866 by stirring up latent fears of women's rights-the same strategy that another generation of Congressmen opposed to civil rights would employ nearly one hundred years later in a failed attempt to defeat the passage of the Civil Rights Act of $1964^{318}$ - a review of the Reconstruction era's social history con-

${ }^{316}$ Id. at 242 (statement of Rep. Cox) (emphasis added) (opposing the 13th Amendment because of its broad sweep and reordering of federalism); see also McConnell, supra note 9, at 216 ("Representative Cox was concerned that if Congress had the power to regulate 'domestic slavery' then perhaps it could exercise this power to "change the relation of ... husband and wife." (omission in original)). Compare Representative Cox's concern to the federalism objections to the VAWA discussed st pra Part II.C.

${ }^{317}$ CONG. GLOBE, 39th Cong., 1st Sess. 1784-85 (1866) (statement of Sen. Cowan). Senator Cowan believed that the Amendment offered no rights for African-Americans who had had "free" status before the Civil War or for anyone born "free." He also protested that the Civil Rights Act of 1866 would "confer[] upon married women, upon minors, upon idiots, upon lunatics, and upon everybody native born in all the States, the right to make and enforce contracts." Id. at 1782.

${ }^{318}$ See Price Waterhouse v. Hopkins, 490 U.S. 228, 243 n.9 (1989) ("The somewhat bizarre path by which 'sex' came to be included as a forbidden criterion for employment-it was included as an attempt to defeat [Title VII]-does not persuade [the Court] that the legislators' statements pertaining to race are irrelevant to cases alleging gender discrimination." (citation omitted)). 
firms that the idea that the Thirteenth Amendment affected familial relations possessed political currency.

First, Congress knew that slavery was more than a system of labor. Both Amar and McConnell argue that Congress considered the personal aspects of slavery when it enacted the Thirteenth Amendment because abolitionist literature had focused on these aspects of slavery for many years before the Civil War. ${ }^{319}$ Congress knew that

[s]lave masters intimately associated with slave women. They were the fathers of slave women. They were the (half) brothers of slave women. They were the sexual partners of slave women. And sometimes they were more than one of these things at the same time. They were having sex with their daughters and their (half) sisters. And this was all very well understood in the literature of abolitionism.

Statements made by Congressmen during the debates support Amar's argument. For example, Senator Clark described slavery as follows:

[Slavery] has degraded the people to the infamous business of raising negroes for sale.... She has practiced concubinage, destroyed the sanctity of marriage, and sundered and broken the domestic ties. She has bound men, women, and children, robbed them, beat them, bruised and mangled them, burned and otherwise murdered them. ${ }^{321}$

Amar and Widawsky argue that this congressional awareness of the public-private nature of slavery explains why the Thirteenth Amendment is applicable to private action. ${ }^{322}$

Second, many of the leaders of the abolitionist movement were also women's rights activists. Via the proposed Thirteenth Amendment, women's rights activists lobbied for abolition, suffrage, and a transformation of the husband-wife relationship. ${ }^{323}$

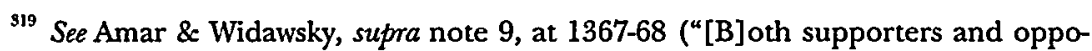
nents of slavery understood that the 'peculiar institution' was tightly bound up with private and intimate relations between persons linked by sex and blood. Although such relations were centuries old, the Thirteenth Amendment broke sharply with custom .... ") ; McConnell, supra note 9, at 218-19 (describing the contents of abolitionist literature); Katyal, supra note 283, at 796-97 (describing the links between prostitution and slavery).

${ }^{320}$ Amar, Women and the Constitution, supra note 9, at 467.

${ }^{\text {921 }}$ CONG. GLOBE, 38th Cong., 1st Sess. 1369 (1864) (statement of Sen. Clark).

${ }^{922}$ See Amar \& Widawsky, supra note 9, at 1368 ("To end slavery was thus to radically restructure this 'private' sphere, and to reorder not simply the political and economic system but the social fabric as well. Accordingly, unlike virtually every earlier provision of the Constitution, the Thirteenth Amendment contained no state action requirement.").

${ }^{323}$ See DuBois, supra note 281, at 113 (noting that women's rights activists "collected over 400,000 signatures ... and Senator Charles Sumner gave them much 
The language used by women's suffrage activists for nearly twenty years before the Thirteenth Amendment debates explicitly evoked images of slavery. ${ }^{324}$ While abolitionist literature focused on the sexual, reproductive, and violent aspects of slavery, women's rights literature called for the vote and other rights as a means to end violence in marriage. ${ }^{325}$ Seneca Falls, the first women's rights conference, occurred in 1848, nearly twenty years before the Thirteenth Amendment debates took place. The Seneca Falls conference report charged that husbands robbed women of their civil rights during marriage:

He has made her, if married, in the eye of the law, civilly dead. He has taken from her all right in property, even to the wages she earns .... In the covenant of marriage, she is compelled to promise obedience to her husband, he becoming, to all intents and purposes, her master-the law giving him power to deprive her of her liberty, and to administer chastisement. ${ }^{326}$

In 1860, at the Tenth National Women's Rights Convention, Elizabeth Cady Stanton, who was more radical than many women's rights activists, advocated divorce as an end to the "legalized prostitution' of coerced marital intercourse and unwilling maternity." ${ }^{327}$ Thus, by the time of the Thirteenth Amendment debates in 1864 and 1865 , women had already been lobbying for change in the husband-

of the credit for the ultimate passage of the Thirteenth Amendment"). The insertion of the words "male inhabitants" into Section 2 of the 14th Amendment dashed the hopes of women's rights advocates that the 13th Amendment would be read expansively to encompass women's suffrage. See U.S. CONST. amend. XIV, § 2. Women's rights activists continued to claim the Reconstruction Amendments, including the 13th, as constitutional authority for women's right to vote. For example, testifying before Congress in the 1870 s to advocate for a statute enfranchising women, Victoria Woodhull argued that "women, white and black, have from time immemorial groaned under what is properly termed in the Constitution "previous condition of servitude."” DuBois, supra note 281, at 124 (quoting 2 HISTORY OF WOMAN SUFFRAGE, supra note 281, at 455). "Thus, when the Thirteenth Amendment abolished slavery, it also abolished the subordinate condition of women." Id. This theory, however, was repudiated by the Supreme Court in Minor v. Happersett, 88 U.S. 162, 178 (1874), which held that voting is not a privilege and immunity of citizenship.

${ }^{324}$ See Siegel, supra note 9, at 2126-29 (noting an example of the way in which the rhetoric of women's rights advocates paralleled that of the abolitionists).

${ }^{325} \mathrm{See} i d$. at 2129 (" $[\mathrm{S}]$ tate-sanctioned violence in the marriage relationship evidenced fundamental defects in its structure and proved the justice of women's demand to participate in the enactment and enforcement of the laws.").

${ }^{326}$ Siegel, supra note 9, at 2128 (quoting REPORT OF THE WOMEN's RIGHTS CONVENTION, HELD AT SENECA FALLS, N.Y., JULY 19TH \& 20TH, 1848, at 6 (Rochester, John Dick 1848)).

${ }^{327}$ Dubois, supra note 281 , at 111 . 
wife relationship for nearly twenty years, drawing upon the language of abolitionists for intellectual and emotional authority.

In addition, according to Reva Siegel, by the end of the Civil War, courts had begun to repudiate the "prerogative of chastisement," an incident of common-law marriage. ${ }^{328}$ Judges began to equate domestic violence with slavery. For example, Siegel quotes an Alabama judge who wrote in an 1871 domestic violence case opinion:

The husband is therefore not justified or allowed by law to use such a weapon, or any other.... The wife is not to be considered as the husband's slave. And the privilege, ancient though it be, to beat her with a stick, to pull her hair, choke her, spit in her face or kick her about the floor ... is not now acknowledged by our law.... [I]n person, the wife is entitled to the same protection of the law that the husband can invoke for himself. ${ }^{329}$

Siegel cautions against a radical reading of this opinion, authored by a former slave holder, because both plaintiff and defendant were recently freed slaves. Rather than heralding a new era for gender relations, the case was more likely an assertion of race privilege; that is, only slave masters were entitled to beat black women. ${ }^{330}$ Despite its racist subtext, the Alabama case demonstrates that legal thinkers in the late-1800s had linked familial violence to slavery. ${ }^{331}$

This historical evidence demonstrates that Congress was not acting in a vacuum when it passed the Amendment and that the settled interpretation that the Amendment reaches only labor relations and racial discrimination may be a judicial gloss added later. ${ }^{392}$ This historical evidence, at the very least, strengthens the argument that, as adopted, the Thirteenth Amendment had the potential to reorder

${ }^{\text {s23 }}$ See Siegel, supra note 9, at 2130.

${ }^{\text {s29 } I d . \text { at }} 2135$ (alterations in original) (emphasis omitted) (quoting Fulgham v. State, 46 Ala. 143, 146-47 (1871)). Siegel also noted that “[t] he Massachusetts Supreme Court rejected a husband's prerogative to chastise his wife in the 1871 case of Commonwealth v. McAfee[, 108 Mass. 458 (1871)]." Id. at 2130.

${ }^{399}$ See Siegel, supra note 9, at 2135-41 (describing a trend of cases in which examples were made out of black men for wife-beating and the Ku Klux Klan's use of "wife beating" as an excuse for attacking black and white men).

ss1 See id. at 2135 ("Though the text of the Fulgham opinion addresses gender relations, the case seems to resonate with racial preoccupations."). The linkage makes more sense when one considers that many slave women were related to their "masters."

${ }^{392}$ See Amar, Women and the Constitution, supra note 9, at 467 ("Women, in short, were in large part the agents and the subjects of the Thirteenth Amendment. They were agents, because women publicly mobilized for the Abolitionist movement; and they were subjects, because half of the people who were emancipated were female."). 
the nineteenth-century familial structure and the status of free women and slave women. ${ }^{333}$ By extension, the Thirteenth Amendment also reaches incidents of nineteenth-century slavery and common-law marriage that persist in preventing women from claiming their full citizenship rights today.

\section{E. Final Objections to a Thirteenth Amendment Theory for the VAWA: Griffin and Its Progeny}

The final objection to Thirteenth Amendment support for the VAWA is that the Thirteenth Amendment covers only racial, not gender, discrimination. Because the VAWA is couched in terms of gender discrimination, this objection could be fatal to a Thirteenth Amendment theory for the civil rights remedy. The Supreme Court has never addressed directly whether the Thirteenth Amendment protects against gender discrimination, dancing around the issue in Griffin $v$. Breckenridge ${ }^{335}$ and its progeny. These cases interpret 42 U.S.C. $§ 1985$ (3), a Reconstruction-era civil cause of action for private conspiracies that deprive others of "the equal protection of the laws, or of equal privileges and immunities under the laws." ${ }^{336}$ In Griffin, the Supreme Court upheld $\S 1985(3)$ as a valid exercise of Congress's Thirteenth Amendment, Section 2 power to regulate the "badges and incidents" of slavery. ${ }^{337}$ The Court's treatment of gender discrimina-

${ }^{393}$ See McConnell, supra note 9, at 215-16 ("Some Congressmen expressed concern that the Thirteenth Amendment had the potential to reach into the private sphere of the home and to alter the traditional relationship between husband and wife.").

${ }^{334}$ See infra Part III.G.

${ }^{835} 403$ U.S. 88 (1971).

${ }^{396} 42$ U.S.C. $\$ 1985(3)$ (1994). The statute provides:

If two or more persons ... conspire or go in disguise on the highway or on the premises of another, for the purpose of depriving, either directly or indirectly, any person or class of persons of the equal protection of the laws, or of equal privileges and immunities under the laws... [and] in any case of conspiracy set forth in this section, if one or more persons engaged therein do, or cause to be done, any act in furtherance of the object of such conspiracy, whereby another is injured in his person or property, or deprived of having and exercising any right or privilege of a citizen of the United States, the party so injured or deprived may have an action for the recovery of damages occasioned by such injury or deprivation, against any one or more of the conId. spirators.

${ }^{337}$ See Griffin, 403 U.S. at 105 ("We can only conclude that Congress was wholly within its powers under section 2 of the Thirteenth Amendment in creating a statutory cause of action for Negro citizens who have been the victims of conspiratorial, racially discriminatory private action aimed at depriving them of the basic rights that the law 
tion under $\S 1985$ (3) might prove instructive in predicting how the Court would rule on a claim that the VAWA is a valid invocation of Congress's Section 2 powers. The VAWA and $\S 1985(3)$ are alike in that both apply to private action. In addition, the gender-related animus requirement in the VAWA is explicitly derived from cases interpreting $\S 1985$ (3), namely Griffin and Bray v. Alexandria Women's Health Clinic. ${ }^{338}$ The VAWA, however, differs from $\S 1985(3)$ in one key respect: The VAWA creates a substantive right-the right to be free from gender-motivated violence-and a remedy, whereas $\S 1985$ (3) is merely a vehicle to address the private abrogation of constitutional and/or statutory rights existing elsewhere. ${ }^{339}$ In Griffin, which involved racial discrimination, ${ }^{340}$ the Court upheld the principle that Congress has the authority to control private action via the Thirteenth Amendment. ${ }^{341}$ Out of a concern that $\S 1985(3)$ not become a general federal tort law, however, the Court held that plaintiffs must show "some racial, or perhaps otherwise class-based, invidiously discriminatory animus behind the conspirators' action." ${ }^{342}$ After Griffin, the question became whether discrimination against women was "otherwise class-based, invidiously discriminatory animus." 343

The Supreme Court has declined to address that issue twice: in Great American Federal Savings $\mathcal{E}^{2}$ Loan Ass'n v. Novotny ${ }^{344}$ and in Bray. ${ }^{345}$ In Novotny, a man claimed the protection of $\S 1985$ (3) when he was fired from his job after expressing support for female employees who

secures to all free men."); see also Jones v. Alfred H. Mayer Co., 392 U.S. 409, 440 (1968) ("Surely Congress has the power under the Thirteenth Amendment rationally to determine what are the badges and the incidents of slavery, and the authority to translate that determination into effective legislation.").

${ }^{\text {s3s }} 506$ U.S. 263 (1993); see supra Part I.C.2 (defining gender-motivated animus and detailing its development in caselaw as applied to $\$ 1985$ and the VAWA).

${ }^{939}$ Because it creates a substantive right, the VAWA is analytically distinct from the Reconstruction-era civil rights statutes, 42 U.S.C. $\S \S 1985(3), 1983$, and 1981 . See Nourse, supra note 2 , at 8 ("[T] hose remedies provide no analogue for the substantive right created by [the VAWA] 'to be free' from gender-motivated violence.").

${ }^{340}$ The action arose when two white men stopped a car of African-Americans and severely beat them. See Griffin, 403 U.S. at 91 .

sil The Court cited Jones $v$. Alfred H. Mayer Co. for the proposition that Congress may legislate against "the badges and the incidents of slavery." Id. at 105 (quoting Jones, 392 U.S. at 440).

${ }^{342}$ Griffin, 403 U.S. at 102. There are additional requirements for a cause of action under $\S 1985$ (3) involving the conspiracy element. See id. at 102-03 (describing the criteria for stating a cause of action under $\$ 1985(3)$ ).
${ }^{349} I d$. at 102.
344 U.S. 366 (1979).
${ }^{315} 506$ U.S. 263 (1993). 
were being denied equal employment opportunities. ${ }^{346}$ Novotny claimed that the "privilege, or immunity" of which he was deprived by the Association officers' conspiracy was his Title $\mathrm{VII}^{\text {s47 }}$ right against sex discrimination in employment. ${ }^{348}$ The U.S. Court of Appeals for the Third Circuit held that women are a protected class under $\S$ 1985(3). ${ }^{349}$ The Supreme Court reversed the Third Circuit decision, but the majority failed to reach the issue of $\S 1985(3)$ and gender discrimination. Instead, the Court narrowly held that " $\$ 1985(3)$ may not be invoked to redress violations of Title VII, ${ }^{350}$ because to do so would allow a plaintiff to circumvent the administrative scheme created by Congress in Title VII. ${ }^{351}$

In his concurrence, Justice Powell implied that he would have held that $\S 1985$ (3) failed to reach gender discrimination. First, Justice Powell stressed that $\S 1985$ (3) neither creates free-standing rights nor provides a remedy for subsequently adopted statutory rights. It only enforces rights already existing in the Constitution. ${ }^{352} \mathrm{He}$ then found no constitutional right to "be free of gender-based discrimination perpetuated solely through private action." ${ }^{353}$ Thus, he concluded that $\S 1985$ (3) does not cover gender discrimination by private actors.

In contrast, Justice White (joined in his dissent by Justices Brennan and Marshall) stated that $\S 1985(3)$ encompasses gender

${ }^{346}$ See Novotny, 442 U.S. at 369 (explaining that petitioner alleged that ${ }^{~}[\mathrm{~h}$ ] is support for the Association's female employees... was the cause of the termination of his employment").

${ }^{347} 42$ U.S.C. $\$ 2000 \mathrm{e}-3$ (a) (1994) (prohibiting an employer from discriminating against employees who have protested those employment practices made illegal by other sections of the Act).

${ }^{348}$ See Novotny, 442 U.S. at 372 (explaining that the primary issue in the case "is whether a person injured by a conspiracy to violate $\$ 704$ (a) of Title VII of the Civil Rights Act of 1964 is deprived of 'the equal protection of the laws, or of equal privileges and immunities under the laws' within the meaning of $\left.\S 1985(3)^{\prime \prime}\right)$.

${ }_{349}$ See Novotny v. Great Am. Fed. Sav. \& Loan Ass'n, 584 F.2d 1235, 1262 (3d Cir. 1978 ) (concluding " $[t]$ hat $\$ 1985(3)$ protects against conspiracies motivated by discriminatory animus against women" and " $[t]$ hat a male injured in furtherance of such a conspiracy has standing to bring an action under $\left.\S 1985(3)^{\prime \prime}\right)$, rev'd, 442 U.S. 366 (1979).

${ }^{350}$ Novotny, 442 U.S. at 378.

351 See id. at 376.

${ }^{352}$ See id. at 379 (Powell, J., concurring) (stating that the reach of $\$ 1985$ (3) "is limited to conspiracies to violate those fundamental rights derived from the Constitution").

${ }^{353}$ Id. at 381 (Powell, J., concurring). 
discrimination. ${ }^{354}$ In a footnote, Justice White wrote: "It is clear that sex discrimination may be sufficiently invidious to come within the prohibition of $\S 1985(3) .{ }^{355}$ Justice White did not specify whether the coverage derives from a constitutional source or a statutory source. ${ }^{356}$

By 1983, in United Brotherhood of Carpenters $\mathcal{E}$ ' Joiners, Local $610 v$. $S c o t t,{ }^{357}$ there were at least four Justices who agreed that $\S 1985(3)$ covers gender discrimination. ${ }^{358}$ Once again, the majority did not address gender discrimination because the case concerned animus against nonunion members. ${ }^{359}$ The majority stated that "it is a close question whether $\S 1985(3)$ was intended to reach any class-based animus other than animus against Negroes and those who championed their cause, most notably Republicans." ${ }^{360}$ In contrast, Justice Blackmun addressed gender-based animus, writing: "[C]ertain class traits, such as race, religion, sex, and national origin, per se meet [the animus] requirement...."

${ }^{354}$ See id. at 388 \& n.5, 388 (White, J., dissenting) ("[T] he words ... in $\S 1985$ (3) refer to substantive rights created or guaranteed by ... the Constitution or federal statutes other than $\S 1985(3) \ldots .$. ").

${ }^{955}$ Id. at 389 n.6 (White, J., dissenting) (citation omitted).

${ }^{956}$ See id. at 388 n.5 (White, J., dissenting) ("I think it clear that $\$ 1985$ (3) encompasses all rights guaranteed in federal statutes as well as rights guaranteed directly by the Constitution.").

${ }^{357} 463$ U.S. 825 (1983).

${ }^{35 s}$ See id. at 853 (Blackmun, J., joined by Brennan, Marshall, \& O'Connor, J., dissenting) (identifying gender as one of the class traits that per se falls under the protection of $\$ 1985(3))$.

${ }^{359}$ See id. at 829 (discussing Griffin v. Breckenridge, 403 U.S. 88, 102 (1971)). The majority held that in order to bring a $\$ 1985(3)$ action grounded in the First Amendment, plaintiffs must show state action or "that the aim of the conspiracy is to influence" the state's activity because First Amendment rights are not protected against private action; and that animus against nonunion workers does not meet the standards for class-based animus. Id. at 829-34.

${ }^{860}$ Id. at 837 . The majority did concede that Congress may have intended $\S 1985$ (3) to have a broad scope, quoting the often-cited language from the legislative history for $\S 1985(3)$ that the section would include conspiracies formed against someone "because he was a Democrat, if you please, or because he was a Catholic, or because he was a Methodist, or because he was a Vermonter." CONG. GLOBE, 42nd Cong., 1st Sess. 567 (1871).

${ }^{851}$ United Brotherhood, 463 U.S. at 853 (Blackmun, J., dissenting). Justice Blackmun devoted most of his dissent to a discussion of Reconstruction Congress members' beliefs that the 14th Amendment created rights of national citizenship that were protected from private action. Thus, it appears that he may have been defining the protected classes in terms of the 14th Amendment, as opposed to the 13th Amendment. See id. at 842-46 (Blackmun, J., dissenting) (arguing that members of the Reconstruction Congress believed that the 14th Amendment conferred a right of national citizenship that could be violated in the absence of state action). 
Interestingly, Justice White, who wrote the Novotny dissent, wrote the opinion of the Court in United Brotherhood; and Justice Blackmun, who wrote the United Brotherhood dissent, had joined the Novotny majority. Neither majority opinion addressed gender. It is therefore possible that in 1979 there were four Justices who would have held that gender discrimination is invidious class-based animus (Justices White, Brennan, and Marshall, plus Justice Blackmun), and that in 1983 there were five (Justices Blackmun, Brennan, Marshall, and O'Connor, plus Justice White). Although the number of Supreme Court Justices holding that position was unclear, many lower federal courts continued to recognize $\S 1985$ (3) claims based on gendermotivated animus. ${ }^{362}$

In Bray v. Alexandria Women's Health Clinic, ${ }^{363}$ the Supreme Court again declined an opportunity to find that $\S 1985$ (3) covered gendermotivated animus. In Bray, abortion clinics tried to use $\S 1985$ (3) to enjoin abortion protesters from protesting at clinics. ${ }^{364}$ The clinics grounded their claim in the right of interstate travel and the right to abortion. ${ }^{365}$ Justice Scalia, writing for the Court, rejected both claims, holding that the right to abortion is protected only against state action and the right of interstate travel was not implicated. ${ }^{366}$ In addition, Justice Scalia wrote that the animus requirements were not met: "women seeking abortions" is not a protected class and discrimination against women seeking abortions is not discrimination against women. ${ }^{367}$ Although Justice Scalia explicitly refused to consider whether $\S 1985$ (3) reaches discrimination against women, he limited the scope of $\S 1985(3)$ if it applied to gender-motivated animus by

${ }^{362}$ See, e.g., Volunteer Med. Clinic, Inc. v. Operation Rescue, 948 F.2d 218, 224 (6th Cir. 1991) (" $[W]$ e find the conclusion inescapable that women constitute a cognizable class under § 1985(3)."); NOW v. Operation Rescue, 914 F.2d 582, 585 (4th Cir. 1990) (affirming the district court's judgment that women are a protected class within the meaning of $\S 1985(3)$ ), rev'd on other grounds sub nom. Bray v. Alexandria Women's Health Clinic, 506 U.S. 263 (1993); Scott v. City of Overland Park, 595 F. Supp. 520, 529 (D. Kan. 1984) (holding that women are a class under $\S 1985(3)$ and citing the United Brotherhood dissent).

${ }^{363} 506$ U.S. 263 (1993).

sos See id. at 266.

${ }^{365}$ See id. at 27478 .

${ }^{366}$ See id. at $276-78$ (stating that $§ 1985$ (3) protects only rights guaranteed against both state and private action, namely the 13th Amendment right to be free from involuntary servitude and the right of interstate travel).

${ }^{367}$ See id. at 269 (rejecting the district court's conclusion that "women seeking abortions" constitutes a protected class). 
importing language from Personnel Administrator v. Feeney. ${ }^{368}$ Potential plaintiffs now must show that discrimination against them is "because of" and not merely "in spite of" their status as women. ${ }^{369}$ Congress adopted this language in the VAWA's definition of gender-motivated animus. ${ }^{370}$

Justices Blackmun, O'Connor, and Souter reiterated that genderbiased discrimination is covered by $\S 1985(3) .{ }^{371}$ Justices Blackmun and O'Connor also criticized the majority for importing the higher standard of discriminatory intent from Fourteenth Amendment state action adjudication into $\S 1985(3) .^{372}$

After Bray, it is still unclear whether a majority of the Supreme Court believes that $\S 1985$ (3) covers invidious animus directed towards women. The VAWA, however, declares that gender-motivated violence against women is a form of gender discrimination and creates a new statutory right. Unlike $\S 1985(3)$, the constitutionality of the VAWA is not dependent on a substantive right to be free of gender discrimination resident in Section 1 of the Thirteenth Amendment, but rather on a determination that gender discrimination in the form of gender-motivated violence is a badge or incident of slavery reachable by congressional action under Section 2. Therefore, Supreme Court opinions regarding gender discrimination and $\S 1985$ (3) are instructive, rather than precedential, to the resolution of the Section 2 question.

\section{F. Modern Battering and Child Abuse as Involuntary Servitude}

When Congress ratified the Thirteenth Amendment, nineteenthcentury chattel slavery was its reference. In the Civil Rights Cases, ${ }^{373}$ the Court granted Congress the authority to legislate against the "badges and incidents" of nineteenth-century chattel slavery. The

442 U.S. 256 (1979).

${ }^{369}$ Bray, 506 U.S. at 271-72 (quoting Feeney, 442 U.S. at 279).

${ }^{370}$ See 42 U.S.C. $\$ 13981$ (d) (1994) (defining a "crime of violence motivated by gender" as a "crime of violence committed because of gender").

${ }^{371}$ See Bray, 506 U.S. at 295-96 (Souter, J., concurring in judgment in part and dissenting in part) (analogizing the equal protection language of $\S 1985$ (3) to the equal protection language of the 14th Amendment); id. at 349 (O'Connor, J., dissenting, joined by Blackmun, J.) ("I would still find in [this] case that 1985(3) reaches conspiracies targeted at a gender-based class .....").

${ }^{572}$ See id. at 353 (O'Connor, J., joined by Blackmun, J., dissenting) ("I see no reason to hold a $\S 1985$ (3) plaintiff to the constitutional standard of invidious discrimination that we employed in our Fourteenth Amendment jurisprudence.").

${ }^{573} 109$ U.S. 3 (1883). 
Thirteenth Amendment, however, is a prohibition of involuntary servitude and slavery for all time. ${ }^{374}$ Therefore, Congress has the power to legislate against the "badges and incidents" of any form of involuntary servitude or slavery in any time.

One example of modern involuntary servitude is child abuse; ${ }^{375}$ another is severe battering. ${ }^{376}$ In an article criticizing the DeShaney decision, Akhil Amar and Daniel Widawsky argue that child abuse is de facto slavery:

Like an antebellum slave, an abused child is subject to near total domination and degradation by another person, and is treated more as a possession than as a person .... [I] f a child runs away, the state typically returns her to parental custody, just as antebellum judges returned fugitive slaves to their masters. And just as antebellum states enforced the legal rights of masters to physical control over their slaves, today's states continue to enforce the legal rights of parents to physical control over their children.

If child abuse and child sexual abuse are slavery, then both are legitimate targets for congressional action under Section 2 of the Thirteenth Amendment. Amar and Widawsky argue that differences between antebellum slaves and abused children should not matter because the Thirteenth Amendment is an absolute prohibition on

${ }^{374}$ The Supreme Court addressed the blanket impact of the 13th Amendment when it stated:

Undoubtedly while negro slavery alone was in the mind of the Congress which proposed the thirteenth article, it forbids any other kind of slavery, now or hereafter. If Mexican peonage or the Chinese coolie labor system shall develop slavery... within our territory, this amendment may safely be trusted to make it void. And so if other rights are assailed by the States which properly and necessarily fall within the protection of these articles, that protection will apply, though the party interested may not be of African descent.

Slaughter-House Cases, 83 U.S. (16 Wall.) 36, 72 (1872).

${ }_{375}$ See Amar \& Widawsky, supra note 9 (positing that the 13th Amendment applies to child abuse).

${ }^{376}$ See McConnell, supra note 9 (arguing that severe battering is involuntary servitude).

37 Amar \& Widawsky, supra note 9, at 1364. Not all parent-child relationships are slavery, only those where "a parent perverts this coercive authority by systematically abusing and degrading his ward-treating his child not as a person but as a chattel, acting as if he had title over the child rather than trusteeship on behalf of the child." Id. Judges may use existing child abuse laws for assistance in determining when an ordinary parent-child relationship converts to slavery. See id. at 1377-78 (noting that most states have laws that provide for criminal punishment for certain kinds of parental misconduct). 
slavery. ${ }^{378}$ The Thirteenth Amendment should supersede the traditional notion that the parent-child relationship is exempted from judicial purview because, if the Thirteenth Amendment never comes between parent and child, then many slave masters would have been able to circumvent the amendment by claiming those slaves who were also their biological children. ${ }^{379}$ By extension, the Thirteenth Amendment should also override the husband-wife relationship when there are conditions of servitude.

Joyce McConnell argues that severe battering also is a modern form of involuntary servitude and should implicate the Thirteenth Amendment. ${ }^{380}$ McConnell sets up her parallel by introducing three case studies of severe battering and comparing the factual scenarios to the factual scenarios in criminal involuntary servitude cases. ${ }^{381}$ McConnell demonstrates that the women in her case studies meet all of the legal requirements for criminal involuntary servitude, ${ }^{352}$ save being in an employer-employee relationship. ${ }^{383}$ McConnell concludes that the lack of an employer-employee relationship should not bar a conclusion that severe battering is involuntary servitude because the cases never define "servitude," focusing instead on the definition of "involuntary"-a standard met in severe battering relationships. ${ }^{344}$

The coercion requirement for Thirteenth Amendment involuntary servitude was established in United States v. Kozminski. ${ }^{385}$ Kozminski

${ }^{978}$ See id. at 1379 (asserting that the "central dictum" of the Civil Rights Cases is that the 13th Amendment prohibits all forms of slavery and involuntary servitude).

${ }^{379}$ See id. at 1374-76 (noting two 19th-century court decisions that stated that parents do not have an absolute right to power over their children).

sso See McConnell, supra note 9 (claiming that some battered women are held in involuntary servitude and that the 13th Amendment should reach them).

See id. (presenting the lives of three battered married women).

${ }^{282}$ See 18 U.S.C. $\$ 1584$ (1994) ("Whoever knowingly and willfully holds to involuntary servitude or sells into any condition of involuntary servitude, any other person for any term, or brings within the United States any person so held, shall be fined under this title or imprisoned not more than five years, or both."); see also id. § 1581(a) ("Whoever holds or returns any person to a condition of peonage... shall be fined ... or imprisoned not more than five years, or both."); $42 \mathrm{id}$. $\$ 1994$ ("The holding of any person to service or labor under the system known as peonage is abolished and forever prohibited in any Territory or State of the United States ....").

ses See McConnell, supra note 9, at 242 ("In each of these ... cases, the level and nature of coercion either equals or exceeds the coercion in the involuntary servitude cases.").

Ssi See id. at 221.

sos 487 U.S. 93I (1988). The Kozminskis kept two mentally retarded men on their farm and forced them to work without pay for up to 17 hours per day. When the two men tried to escape, they were brought back to the farm, and one was threatened with institutionalization. See id. at 934-35. 
involved criminal charges under 18 U.S.C. $\S 1584$ and 18 U.S.C. $\S 241 .^{386}$ The Court in Kozminski defined involuntary servitude as "a condition of servitude in which the victim is forced to work for the defendant by the use or threat of physical restraint or physical injury, or by the use or threat of coercion through law or the legal process." ${ }^{387}$ Psychological coercion without the threat of force or legal sanction is insufficient to show involuntary servitude. ${ }^{388}$ Justice Brennan disagreed with the majority on the issue of psychological coercion, writing that such actions as isolating a victim, threatening to harm a victim's children, and denying a victim pay for her labor would be sufficient to show involuntariness when a victim is held in "a relation of complete domination and lack of personal liberty resembling the conditions in which slaves were held prior to the Civil War." $" 889$

One issue when applying the involuntary servitude standards to the domestic violence context is whether the initial voluntary entrance into a relationship with the abuser nullifies a claim that the servitude is "involuntary." First, criminal involuntary servitude does not require that the victim be completely unable to leave. For example, in United States v. Bibbs, the Fifth Circuit held that it was irrelevant to a conviction for holding a person in involuntary servitude that the victim may have had opportunities to leave if the victim so feared for her safety that she was afraid to leave. ${ }^{390}$

Second, can a woman really leave? Statistics show that a woman is more likely to be killed after separation from an abusive partner than before separation. $^{391}$ In addition, because severe battering often in-

${ }^{386}$ Section 241 of Title 18 of the U.S. Code criminalizes conspiracies "to injure, oppress, threaten, or intimidate any person ... in the free exercise or enjoyment of any right or privilege secured to him by the Constitution or laws of the United States, or because of his having so exercised the same." 18 U.S.C. $\$ 241$. In this case, the substantive right is the 13th Amendment right to be free from involuntary servitude.

s37 487 U.S. at 952.

sss See id. at 949 (rejecting an overly broad interpretation of involuntary servitude).

${ }^{s 99}$ Id. at 961 (Brennan, J., concurring in judgment); see also id. at 969 (Stevens, J., concurring in judgment) ("I agree with Justice Brennan that the reach of [\$ 1584] extends beyond compulsion that is accompanied by actual or threatened physical means or by the threat of legal action.").

${ }^{390} 564$ F.2d 1165, 1168 (5th Cir. 1977).

${ }^{391}$ See Martha R. Mahoney, Legal Images of Battered Women: Redefining the Issue of Separation, $90 \mathrm{MICH}$. L. REV. 1, $72-75$ (1991) (detailing cases of murder that occurred after women left abusive partners). Mahoney explains: "At the moment of separation ... the batterer's quest for control often becomes most acutely violent and potentially lethal." Id. at 5-6. The Bureau of Justice Statistics found divorced or separated women had "higher rates of violence by intimates ( 16 per 1000 persons) than women 
volves systematic economic and social isolation of the victim, the abused woman may lack the financial resources to support herself. ${ }^{392}$ Also, her batterer may stalk her ${ }^{393}$ or show up at her workplace. ${ }^{394}$ When the woman has children, the economic and safety problems are magnified. Batterers may threaten and abuse the children, ${ }^{395}$ kidnap them after the mother leaves, or file for custody of the children in common. ${ }^{396}$ Compare this to the plight of nineteenth-century slave women who ran away from plantations much less frequently than did male slaves because of fear for children left behind, or because it would be too difficult to escape with children in tow. ${ }^{397}$ Thus, the perceived notion that women voluntarily enter abusive relationships would not necessarily defeat a claim of involuntary servitude.

Another objection to the use of criminal involuntary servitude standards in the domestic violence context is that victims of domestic violence are ordinarily not in an employer-employee relationship with their batterers, excluding those women who work with their batterers in a family business. However, the type of work performed by women in some battering relationships, such as housework, may bring the conflict within the realm of an employer-employee relationship. In Bernal v. United States, ${ }^{398}$ for example, the court held that a female domestic laborer forced to perform housework to pay off a debt was

who never married (7 per 1000) or married women (1.5 per 1000)." BUREAU OF JUSTICE STATISTICS, U.S. DEP'T OF JUSTICE, VIOLENCE BETWEEN INTIMATES 2 (1994).

${ }^{532}$ See Mahoney, supra note 391, at 23 (stating that women become poorer after divorce, and that many homeless women are homeless because they left abusive environments).

${ }^{393}$ See U.S. DEP'T OF JUSTICE, DOMESTIC Violence AND STALKING: THE SECOND ANNUAL REPORT TO CONGRESS UNDER THE VIOLENCE AGAINST WOMEN ACT (1997) (noting the observation of criminal justice officials that stalking occurs when women leave their abusers).

${ }^{994}$ See generally Esta Soler, Reaching Out, VIOLENCE AGAINST WOMEN ACT NEWS (Violence Against Women Office, U.S. Dep't of Justice, Washington, D.C.), Sept. 1996, at 1,2 (noting that the U.S. Department of Justice estimates that in the " 60,000 incidents of on-the-job violence each year, the victims know their attackers intimately").

${ }^{395}$ See NATIONAL COALITION AGAINST DOMESTIC VIOLENCE, FACT SHEET - WOMAN ABUSE ... CHILD ABUSE (1994) [hereinafter FACT SHEET] (citing statistics showing a link between child abuse and domestic violence).

${ }^{956}$ See id. (citing studies that show that " $[\mathrm{m}]$ ore than $50 \%$ of child abductions result from domestic violence," and that abusive men use custodial access to punish their victims).

${ }^{397}$ See WHITE, supra note 306, at 70-75 (listing differential sex ratios of fugitive slaves, positing that responsibility for children caused the discrepancy, and illustrating the point with slave women's narratives); $c f$. FACT SHEET, supra note 395 (stating that many women return to abusive relationships out of fear of losing custody of their children).

241 F. 339 (5th Cir. 1917). 
being held in peonage. ${ }^{399}$ In addition, battered women are often subject to forced sex and even to forced prostitution, both covered activities. Although the idea of rape as a "service" is abhorrent, the court in Pierce $v$. United States held that forced prostitution constituted involuntary servitude. ${ }^{400}$ Therefore, battering relationships are not necessarily exempted by the type of services performed.

McConnell's argument that battering relationships should be considered involuntary servitude despite the lack of an employeremployee relationship is strengthened by the argument that the Thirteenth Amendment covers the private and familial aspects of slavery discussed above. ${ }^{401}$ Once severe battering is equated with involuntary servitude, Congress may legislate directly against it and any of its incidents under Section 2 of the Thirteenth Amendment.

If the Doe v. Doe case were to go up for Supreme Court review, McConnell's arguments might be sufficient because Doe v. Doe involved a long-term severe battering relationship. ${ }^{402}$ Crimes of violence motivated by gender, however, also include a wide range of isolated violent crimes and cases of battering that would not meet McConnell's expanded definition of involuntary servitude. ${ }^{403}$ One argument that could encompass all crimes of violence motivated by gender is that the other forms of violence are part of a continuum of violence against women and represent incidents of the modern involuntary servitude of severe battering. Each crime of violence committed, such as sexual assault, felonious assault, murder, or kidnapping, could occur in any given battering relationship. This argument requires taking an additional step from the thesis that severe domestic violence is involuntary servitude and may be further than a court would be willing to go. Therefore, McConnell's argument that severe battering is involuntary servitude ${ }^{404}$ and Amar and Widawsky's argument that

${ }^{399}$ See id. at 341.

${ }^{400} 146$ F.2d 84, 86 (5th Cir. 1944) (finding sufficient evidence to support a claim of peonage when young women were forced to perform acts of prostitution to pay off debts).

${ }^{401}$ See supra Part III.C.

${ }^{402}$ Jane Doe was trapped in an abusive relationship for 17 years that shared many characteristics of a master-slave relationship. See Doe v. Doe, 929 F. Supp. 608, 610 (D. Conn. 1996).

${ }^{403}$ For example, an isolated rape, perpetrated with the requisite gender-motivated animus, could give rise to a VAWA claim. See supra Part I.C.

${ }^{104}$ See McConnell, supra note 9. 
child abuse is slavery ${ }^{405}$ may only provide constitutional justification for VAWA cases involving severe battering or child abuse.

\section{G. Modern Violence Against Women as an Incident of Nineteenth-Century Slavery and Marriage}

A theory that embraces all crimes of violence motivated by gender is that gender discrimination in the form of violence constitutes a badge and incident of nineteenth-century slavery and of a particular variety of "involuntary servitude," namely, nineteenth-century marriage. Part III.C showed how the violence perpetrated against slave women was differentiated based on gender, and Part II.A.2 detailed how married women were subject to chastisement and deprived of payment for their work in a gender-differentiated fashion under common-law marriage. The violent acts experienced by women today are the same violent acts experienced by slave women and chastised wives in the nineteenth century.

In Frontiero v. Richardson, ${ }^{406}$ Justice Brennan took judicial notice of the parallels between chattel slavery and common-law marriage:

[T]hroughout much of the 19th century the position of women in our society was, in many respects, comparable to that of blacks under the pre-Civil War slave codes. Neither slaves nor women could hold office, serve on juries, or bring suit in their own names, and married women traditionally were denied the legal capacity to hold or convey property or to serve as legal guardians of their own children. ${ }^{407}$

Andrea Brenneke links battering today with the status of white women under the law of the nineteenth century:

[B]attered women sometimes find themselves in relationships in which they have lost all freedom of movement and integrity of body and mind to the control and coercion of their husbands. Such a system of "private" involuntary servitude today has its cultural origins in "public" laws which treated women as the property of their husbands, allowed husbands to discipline their wives through violence and prevented women from participating in the democratic process.

If one accepts the ideas that (1) slavery and common-law marriage were two forms of legal status that denied women their full citi-

${ }^{405}$ See Amar \& Widawsky, supra note 9.

${ }^{106} 411$ U.S. 677, 688 (1973) (holding that classifications based on sex are "inherently suspect").

${ }^{407} I d$. at 685 .

${ }^{109}$ Brenneke, supra note 49 , at 41 . 
zenship rights; (2) the purpose of the Thirteenth Amendment was to give slaves and people held in involuntary servitude full citizenship rights; and (3) today, violence prevents women from enjoying the citizenship rights guaranteed by the Thirteenth Amendment, then a Thirteenth Amendment theory for the VAWA appears logical. Another way of stating this argument is that because Congress has the authority to legislate against the incidents of both slavery and involuntary servitude, it has the authority to legislate against the remainders of nineteenth-century legal status that still threaten women's enjoyment of their Thirteenth Amendment citizenship rights, including the right to be free from slavery and involuntary servitude and the rights listed in the Civil Rights Act of $1866{ }^{409}$

When making arguments in this area, it is important to remember that, while there are many similarities between the lack of citizenship rights possessed by white women in nineteenth-century marriage and black women held in slavery, nineteenth-century slavery and marriage were fundamentally different. McConnell, for example, adamantly disagrees with any line of reasoning that analogizes white women's coverture to black women's slavery:

No matter how rhetorically useful this metaphor... may seem now, it ... remains grossly inaccurate and inherently racist. It obscure [s] the fact that white women were slaveholders or beneficiaries of the slave system. It fail[s] to recognize that even though there were significant legal, political and social restraints on white women, they did not as a class suffer in the way that African Americans did under slavery. Finally, it ignore[s] the fact that African American women were slaves and that other women were not, no matter what their subordinate legal or socioeconomic status. ${ }^{410}$

One way to avoid the inaccurate metaphor is to argue that modern gender-motivated violence is a carryover from or incident of chattel slavery, the involuntary servitude of nineteenth-century marriage, or both, depending on the race of the victim. Black women may argue that gender-motivated violence against them reflects the differential sex-based violence that occurred as part of chattel slavery ${ }^{411}$ and/or that the gender discrimination is an incident of the commonlaw form of marriage that included the prerogative of chastisement and the lack of other citizenship rights. Black women may claim both because after they were freed from slavery, they ostensibly were sub-

\footnotetext{
109 See infra text accompanying notes 420-21.

${ }^{110}$ McConnell, supra note 9, at 207-08 (footnotes omitted).

${ }^{111}$ See supra Part III.C.
} 
ject to the same lack of rights as white women, at least as a constitutional matter. ${ }^{412}$ White women may argue only the second theory. ${ }^{413}$

There is some support in the legislative history of the VAWA for a Thirteenth Amendment theory positing that violence today is a badge and incident of slavery and the prerogative of chastisement. At the 1991 Senate Hearings, Professor Burt Neuborne argued that Congress had the authority to enact the VAWA because gender discrimination in the form of gender-motivated violence is a badge and incident of slavery or involuntary servitude. ${ }^{414}$ The 1991 Senate Committee Report claimed that the purpose of the civil rights remedy is to take "aim at gender-discrimination prohibited under the [Thirteenth A]mendment." 115 Note that the section in a later 1993 Senate Report on Congress's power to enact the VAWA, which incorporated many of the statements from the 1991 report, dropped this reference. ${ }^{416}$

Neuborne testified before Congress that society had long treated women "as chattel" or "as slaves," and that Congress "should recognize that there are badges and incidents to the chattel slavery that women were subjected to." based violence is denying women an equal status in society, it is precisely analogous to the badges and incidents of Afro-American slavery swept away by Congress and the courts in cases following Jones." ${ }^{418}$ Neuborne concluded that Congress has authority under Section 2 of the Thirteenth Amendment to legislate against the badges of and incidents to women's status as chattel-gender-motivated crimes of violence. ${ }^{419}$

${ }^{412}$ By "constitutional matter," I mean theoretically as a constitutional matter. Because of continued racism in society, black women still do not enjoy the same rights as white women.

${ }^{413}$ By referring only to black and white women, I do not mean to suggest that other women may not assert a 13th Amendment claim under the VAWA. I have specifically mentioned black and white women, because they are the women with whom the Reconstruction Congress was concerned. Today, an Asian woman, for example, could also claim that she inherited her status in contemporary society from the gender-differentiated legal status of white women under common-law marriage.

${ }^{114}$ See Violence Against Women: Victims of the System: Hearings on S. 15 Before the Senate Comm. on the Judiciary, 102d Cong. 80 (1991) (statement of Burt Neuborne, Professor of Law, New York University) [hereinafter Neuborne].

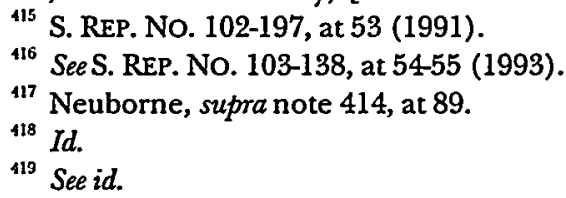


Another badges-and-incidents argument is that genderdifferentiated violence also inhibits women's citizenship rights as traditionally defined under the Thirteenth Amendment. Recall that the Civil Rights Act of 1866 and the Civil Rights Cases defined the rights of citizenship as follows:

[A]ll persons ... shall have the same right ... to make and enforce contracts, to sue, be parties, and give evidence, to inherit, purchase, lease, sell, hold, and convey real and personal property, and to full and equal benefit of all laws and proceedings for the security of person and property, as is enjoyed by white citizens....

The Civil Rights Cases then granted Congress the authority to regulate deprivations of these rights. ${ }^{421}$ Therefore, if private violence today precludes women from exercising any of these rights, then Congress may regulate it.

In relation to applying the commerce power to the VAWA, Congress heard extensive testimony concerning the effect that gendermotivated violence has on women's employment choices. For example, the Senate found that fear of gender-based discriminatory violence "reduces employment opportunities" by "deter[ring] women from taking jobs in certain areas or at certain hours that pose a significant risk of such violence. ${ }^{422}$ This deterrence can also be viewed as an inhibition of the right to form contracts of employment.

\section{CONCLUSION}

The civil rights remedy of the Violence Against Women Act may be at risk of being held unconstitutional under a Commerce Clause theory in the aftermath of United States $v$. Lopez ${ }^{423}$ The historical domestic relations exclusion of divorce, custody, and alimony cases from federal courts may add logical resonance to a decision striking down the VAWA under the Commerce Clause. Although five district courts have upheld the remedy under the Commerce Clause, one did so "reluctantly," citing federalism concerns, and two others certified the question on interlocutory appeal. In addition, if a reviewing court determines that the VAWA is unconstitutional under the Commerce

${ }^{120}$ Civil Rights Act of 1866 , ch. 31, $\S 1,14$ Stat. 27 (codified as amended at 42 U.S.C. $\S 1981$ (1994)); see The Civil Rights Cases, 109 U.S. 3, 16 (1883) (quoting this language).

\footnotetext{
121109 U.S. at 20.

${ }^{122}$ S. REP. No. 103-138, at 54 (1993); see supra Part I.E.2.

${ }^{423} 514$ U.S. 549 (1995).
} 
Clause, it may also draw on the historically pedigreed doctrines of state action and marital property, and strike down the remedy under the Fourteenth Amendment as well. Consequently, there is a need for an alternative basis for congressional power to enact the remedy. Congress's Thirteenth Amendment, Section 2 power to legislate against actual conditions of, badges of, and incidents to slavery and involuntary servitude provides this alternative basis of authority.

The VAWA includes a private civil rights remedy designed to combat gender discrimination that takes the form of crimes of violence motivated by gender. The Thirteenth Amendment applies regardless of state action, federalism, and privacy because it has always reached private action and represented a fundamental change in federalism when adopted. Thus, there are two possible theories that provide Thirteenth Amendment authority. First, Congress had the power to enact the VAWA, at least in regard to domestic violence, child abuse, and sexual abuse of children, because those three conditions are modern forms of involuntary servitude. Second, Congress had the power to enact the VAWA because modern gender discrimination in the form of gender-motivated violence is an incident of both nineteenth-century slavery and the nineteenth-century involuntary servitude of common-law marriage. Although neither of these theories has been argued in a case concerning the VAWA, lawyers who bring VAWA suits and face constitutional challenges should consider including a Thirteenth Amendment defense of the VAWA in their arguments. 
